\title{
Guiding Principles for Sustainable Existing Buildings: Radiochemical Processing Laboratory
}

J Pope

November 2013

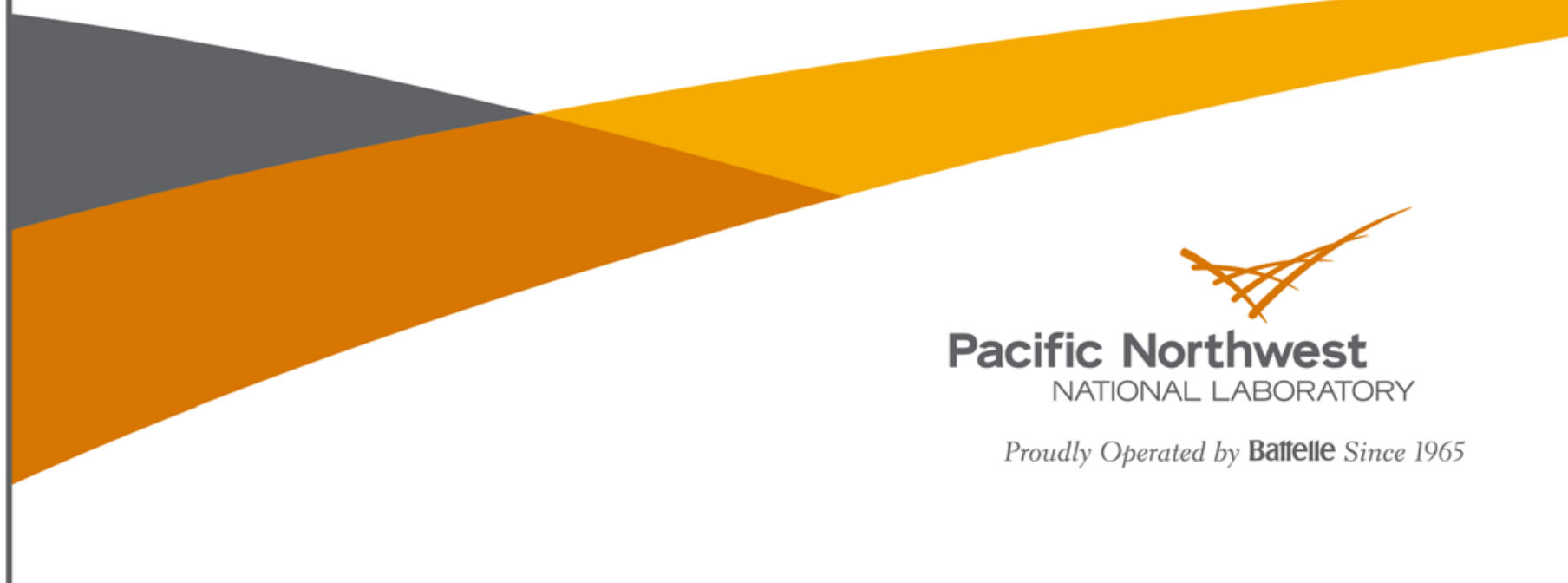




\title{
DISCLAIMER
}

This report was prepared as an account of work sponsored by an agency of the United States Government. Neither the United States Government nor any agency thereof, nor Battelle Memorial Institute, nor any of their employees, makes any warranty, express or implied, or assumes any legal liability or responsibility for the accuracy, completeness, or usefulness of any information, apparatus, product, or process disclosed, or represents that its use would not infringe privately owned rights. Reference herein to any specific commercial product, process, or service by trade name, trademark, manufacturer, or otherwise does not necessarily constitute or imply its endorsement, recommendation, or favoring by the United States Government or any agency thereof, or Battelle Memorial Institute. The views and opinions of authors expressed herein do not necessarily state or reflect those of the United States Government or any agency thereof.

\author{
PACIFIC NORTHWEST NATIONAL LABORATORY \\ operated by \\ BATTELLE \\ for the \\ UNITED STATES DEPARTMENT OF ENERGY \\ under Contract DE-AC05-76RL01830
}

Printed in the United States of America

Available to $\mathrm{DOE}$ and $\mathrm{DOE}$ contractors from the

Office of Scientific and Technical Information,

P.O. Box 62, Oak Ridge, TN 37831-0062;

ph: (865) 576-8401

fax: $(865) 576-5728$

email: reports $a$ adonis.osti.gov

Available to the public from the National Technical Information Service

5301 Shawnee Rd., Alexandria, VA 22312

ph: (800) 553-NTIS (6847)

email: orders $a$ ntis.gov <http://www.ntis.gov/about/form.aspx $>$

Online ordering: http://www.ntis.gov 


\section{Guiding Principles for Sustainable Existing Buildings: Radiochemical Processing Laboratory}

J Pope

November 2013

Prepared for

the U.S. Department of Energy

under Contract DE-AC05-76RL01830

Pacific Northwest National Laboratory

Richland, Washington 99352 
Signatures

Prepared by:

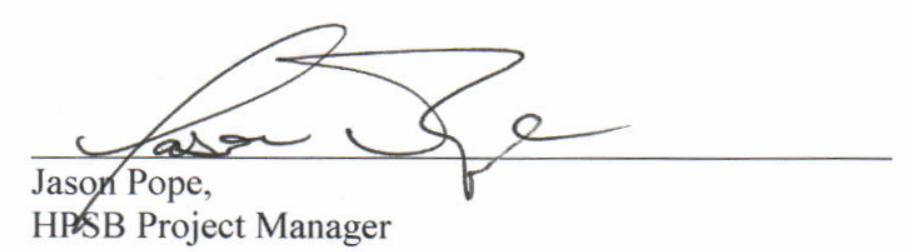

Concur:

Concur:

Approved by:

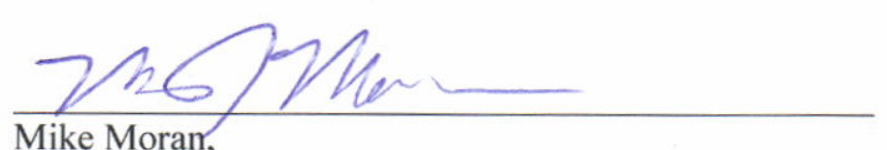

Mike Moran,

Sustainability Program Manager

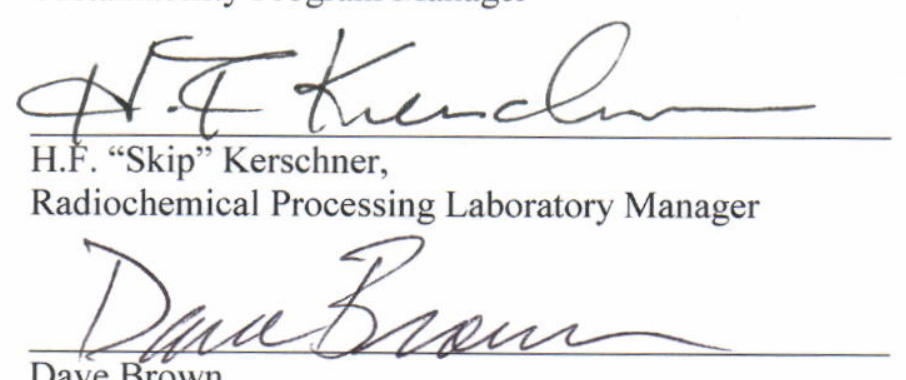

Dave Brown, Chief Engineer
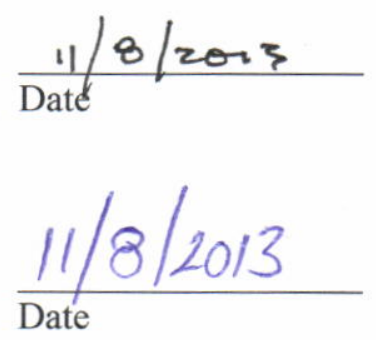

Nor 11, 2013

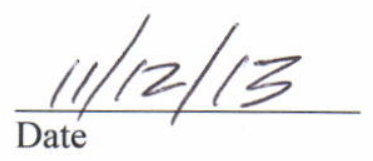

iii 


\section{Acronyms and Abbreviations}

ASHRAE American Society of Heating, Refrigerating, and Air-Conditioning Engineers

CFC chlorofluorocarbons

DOE Department of Energy

DSOM Decision Support for Operations and Maintenance

EISA Energy Independence and Security Act (2007)

EMSL Environmental Molecular Science Laboratory

EMS Environmental Management System

EO Executive Order

EPA Environmental Protection Agency

EPEAT Electronic Product Environmental Assessment Tool

F\&O Facilities and Operations

FIMS Facilities Information Management System

FMCS facility monitoring and control system

FUA Facility User Agreement

GRI Global Reporting Index

HCFC hydrochlorofluorocarbon

IPM integrated pest management

MARS Maintenance and Repair Forecasting application

MOU Memorandum of Understanding

PM periodic maintenance

PNNL Pacific Northwest National Laboratory

PV photovoltaic

RPL Radiochemical Processing Laboratory

SME subject matter expert

SSP Site Sustainability Plan

U.S. United States

USDA United States Department of Agriculture

VOC volatile organic compound 


\section{Contents}

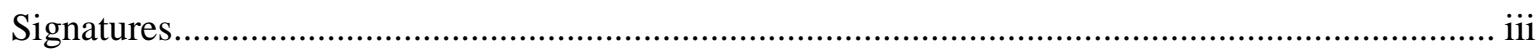

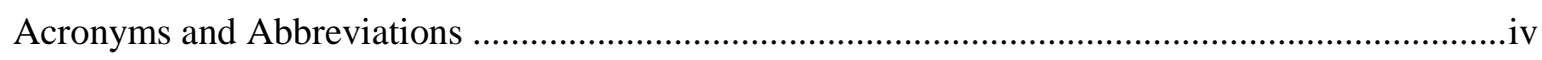

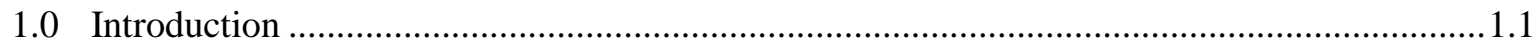

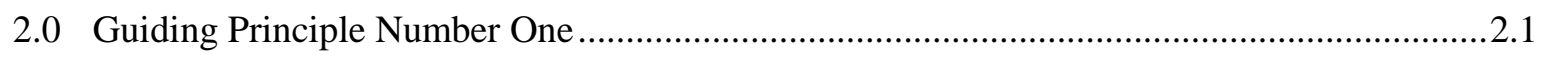

2.1 Integrated Assessment, Operation, and Management ................................................ 2.1

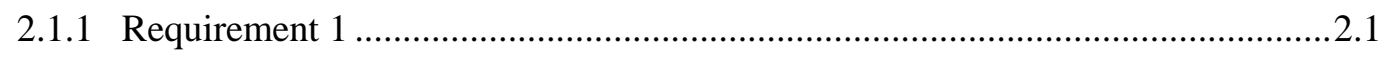

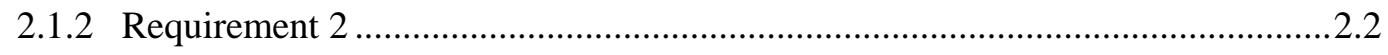

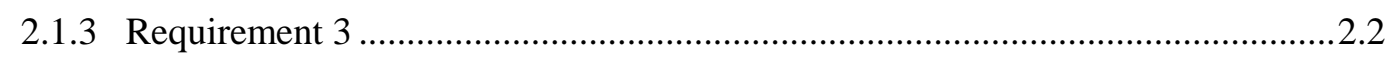

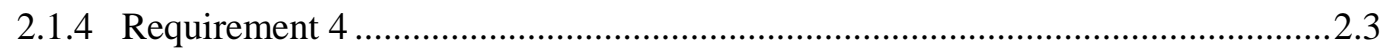

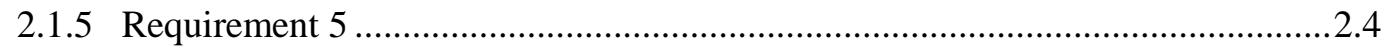

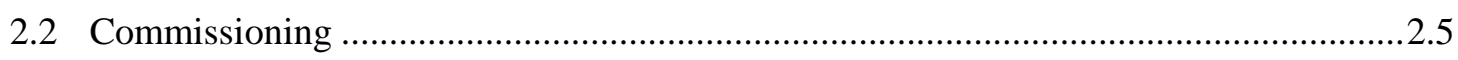

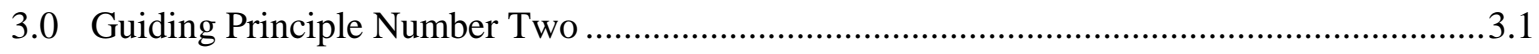

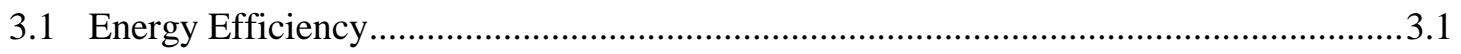

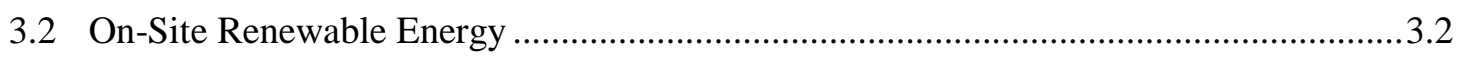

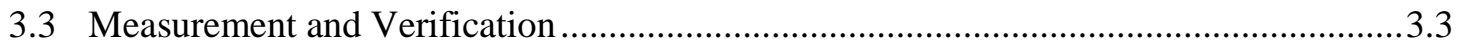

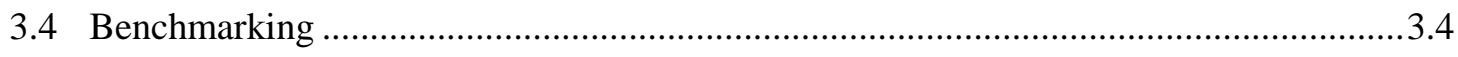

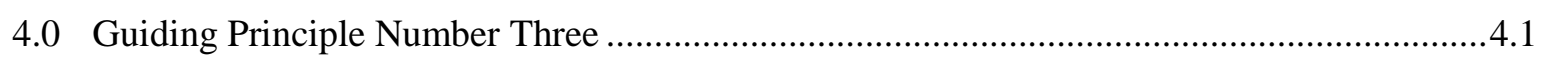

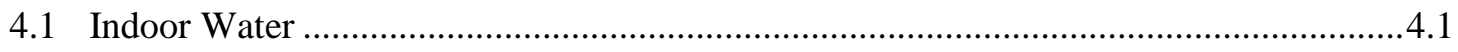

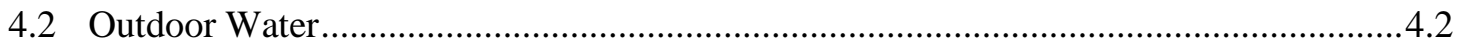

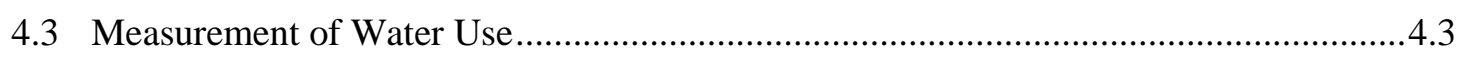

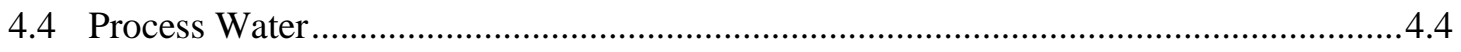

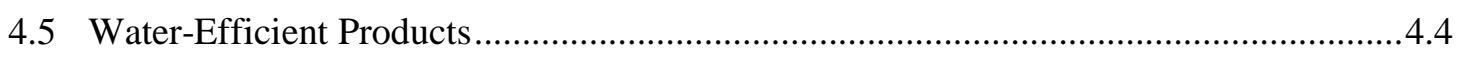

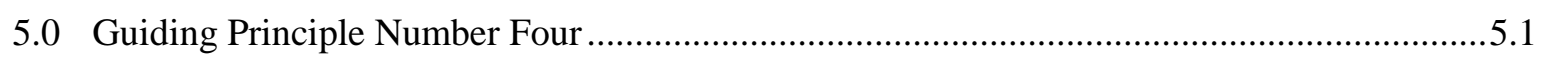

5.1 Ventilation and Thermal Comfort ................................................................................ 5.1

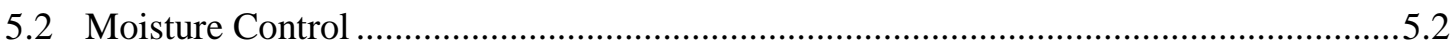

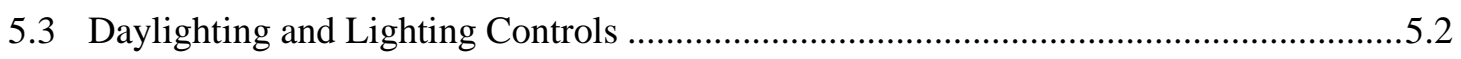

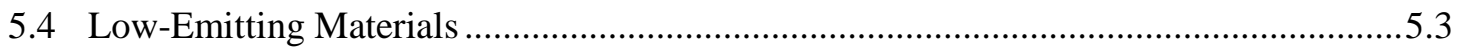

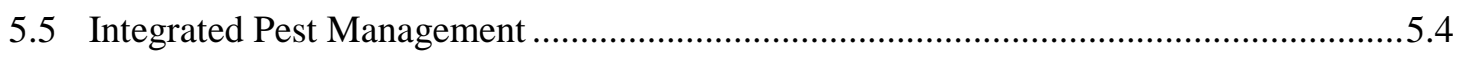

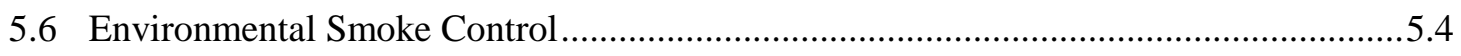

6.0 Guiding Principle Number Five ................................................................................... 6.1

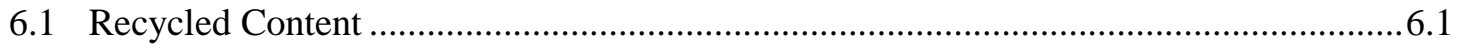

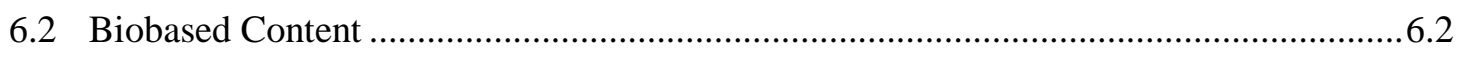

6.3 Environmentally Preferable Product .......................................................................... 6.2

6.4 Waste and Materials Management .......................................................................... 6.3

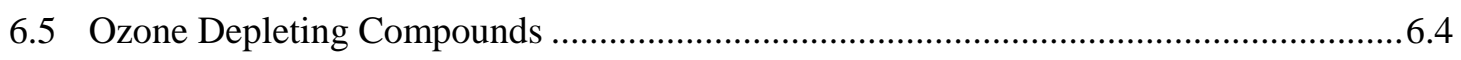

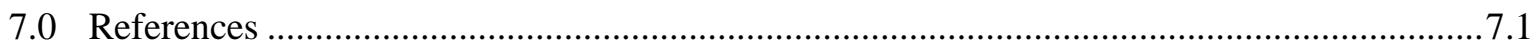




\section{Figures}

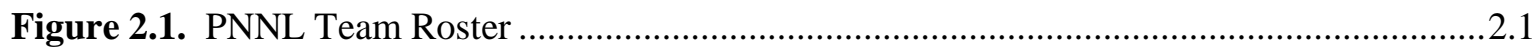

Figure 2.2. Battelle - Pacific Northwest Division ISO 14001:2004 Registration .........................2.2

Figure 2.3. Example of the Porcelain Press Newsletter ............................................................2.3

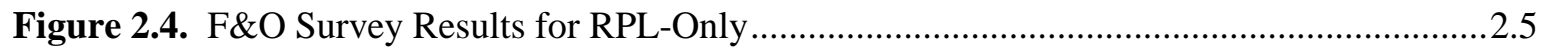

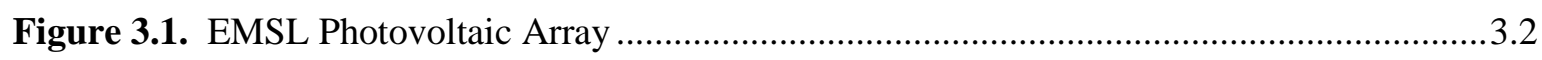

Figure 3.2. EMSL Solar Hot Water Heater.............................................................................

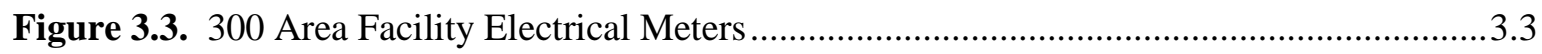

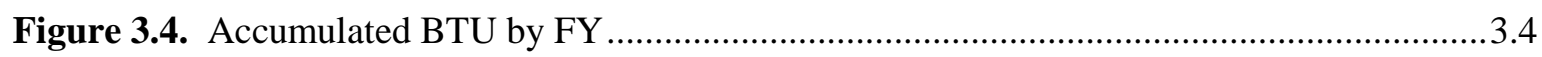

Figure 3.5. BTU/Day/ $\mathrm{Ft}^{2}$ vs. Monthly Average Temperatures .................................................. 3.5

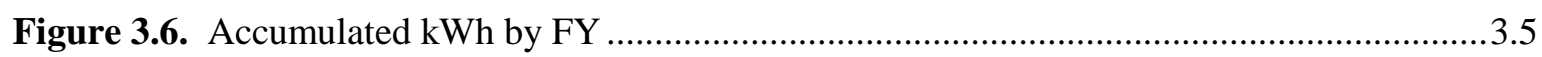

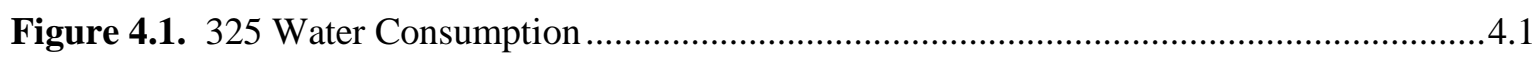

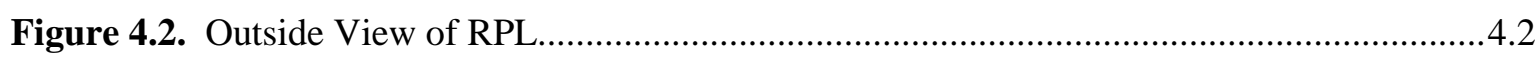

Figure 4.3. Metasys System Trend Example for Potable Water Use at RPL ...............................4.3

Figure 4.4. Water-Efficient Products Installed at RPL ..........................................................4.5

Figure 5.1. Sample Trace Showing 1 Year of Temperature Data in RPL Room 928 ...................5.1

\section{Tables}

Table 3.1. 2003 and 2013 Comparison of Energy Consumption ...................................................

Table 4.1. 235 Water Consumption (CCF) …............................................................................ 4.1

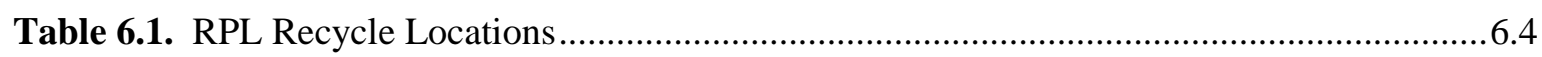

Table 6.2. RPL Units Containing HCFC Refrigerants............................................................. 6.4 


\subsection{Introduction}

In 2006, the United States (U.S.) Department of Energy (DOE) signed the Federal Leadership in High Performance and Sustainable Buildings Memorandum of Understanding (MOU), along with 21 other agencies. The MOU originally committed DOE to follow the Guiding Principles for new construction and major renovations and was revised in 2008 to include transforming existing buildings into high performance sustainable buildings. The Guiding Principles for sustainable existing buildings focuses on the following five topic areas:

1. Employ Integrated Assessment, Operation, and Management Principles

2. Optimize Energy Performance

3. Protect and Conserve Water

4. Enhance Indoor Environmental Quality

5. Reduce Environmental Impact of Materials.

Executive Order (EO) 13423, “Strengthening Federal Environmental, Energy, and Transportation Management” and EO 13514, "Federal Leadership in Environmental, Energy, and Economic Performance” both require that 15 percent of an agency's existing buildings and leases meet the Guiding Principles by 2015. Additionally, EO 13514 requires agencies to make annual progress towards 100 percent of buildings meeting the Guiding Principles.

Pacific Northwest National Laboratory (PNNL) is exceeding this requirement and, currently, about 25 percent of its buildings are High Performance and Sustainable Buildings. The pages that follow document the Guiding Principles conformance effort for the Radiochemical Processing Laboratory (RPL) at PNNL. The RPL effort is part of continued progress toward a building inventory that is 100 percent compliant with the Guiding Principles.

The included documentation is intended to provide a narrative of how RPL complies with each of the Guiding Principles requirements. These narratives draw from the many sources that are explained in the text and rely on extensive data collection. The descriptions that follow point to each of these sources, providing the reader with specific policies, procedures, and data points. 


\subsection{Guiding Principle Number One}

\subsection{Integrated Assessment, Operation, and Management}

Guiding Principle One, Integrated Assessment, Operation, and Management, requires us to use an integrated team to develop and implement policy regarding sustainable operations and maintenance. The integrated team at PNNL is detailed on the team roster in Figure 2.1 and works together to meet the five requirements discussed below.

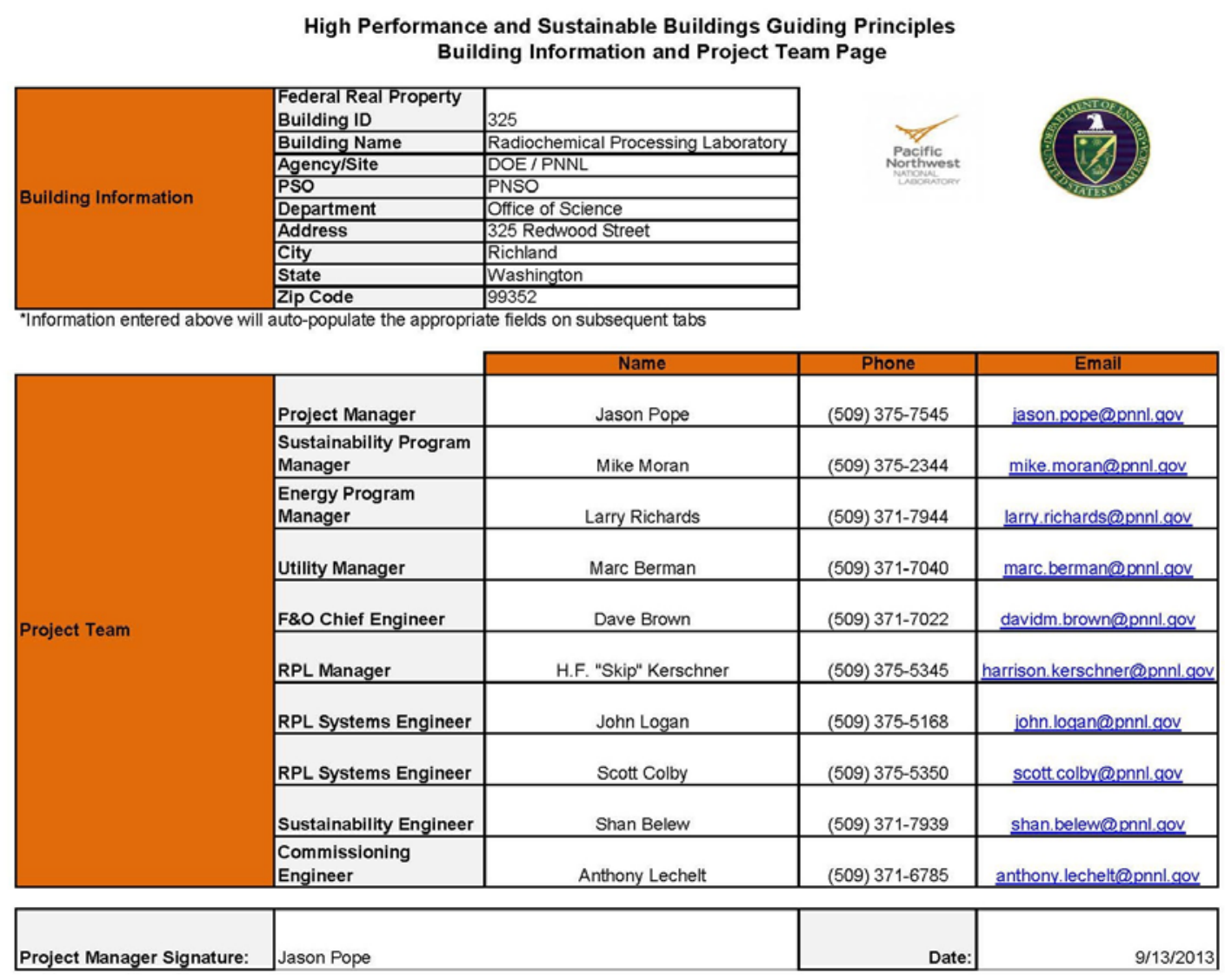

Figure 2.1. PNNL Team Roster

\subsubsection{Requirement 1}

The first requirement asks us to "incorporate sustainable operations and maintenance practices within the appropriate Environmental Management System (EMS).” PNNL is committed to providing a safe and healthy working environment for all staff; protecting the general public and the environment from unacceptable environmental, safety, and health risks; and operating in a manner that protects and restores the environment. 
Since 2002, we have used an ISO 14001 registered EMS (see Figure 2.2) as a tool to help us measure our environmental performance through a rigorous process of goal-setting, planning, monitoring, and reporting. The Laboratory's sustainability goals development and implementation is spear-headed by an EMS core team, which consists of representatives from key EMS programs. In 2009, we incorporated into our EMS a set of sustainability performance indicators aligned with the Global Reporting Initiative (GRI) sustainability reporting framework, to further improve management of our overall sustainability performance. Annually, the results of our sustainability efforts are captured in a Sustainability Report. Auditing conducted by independent third party has verified that the PNNL's Sustainability Program is fully integrated into the Laboratory's EMS and meets the requirements of EO 13514.

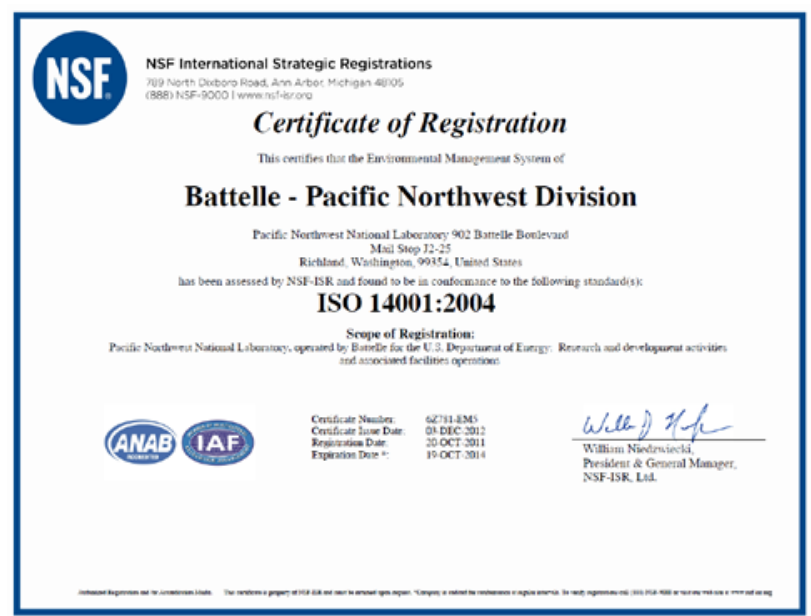

Figure 2.2. Battelle - Pacific Northwest Division ISO 14001:2004 Registration

\subsubsection{Requirement 2}

The second requirement asks us to "assess existing condition and operational procedures of the building and major building systems and identify areas for improvement.” The Facility Management and Operations Program Description at PNNL identifies the Maintenance and Repair Forecasting application (MARS) as a key system implementation. The MARS system supplies detailed annual forecasts of maintenance costs, staffing requirements, and deferred maintenance. Additional costs of special safety and security procedures at PNNL are part of the annual assessment.

\subsubsection{Requirement 3}

Requirement three calls for us to "establish operational performance goals for energy, water, material use and recycling, and indoor environmental quality, and ensure incorporation of these goals throughout the remaining lifecycle of the building." As required by DOE, the PNNL EMS core team develops an annual Site Sustainability Plan (SSP). PNNL's progress towards the performance goal categories listed above is captured within the SSP.

Indoor environmental quality is detailed in the Facility User Agreement (FUA), an agreement that formally captures the physical attributes of the facility and operational boundaries, among other things. This agreement is between the Facilities and Operations (F\&O) Directorate and the directorates 
performing research in RPL, the Energy and Environmental Directorate, and the National Security Directorate.

\subsubsection{Requirement 4}

This requirement asks the user to "incorporate a building management plan to ensure that operating decisions and tenant education are carried out with regard to integrated, sustainable building operations and maintenance.” This requirement is fulfilled at a high level in the annual Laboratory Plan, where PNNL's commitment to sustainability is underscored as a key plan component. This emphasis by top Lab management sets the tone for thousands of lower-level decisions made each year in support of integrated, sustainable building operations and maintenance.

At a more detailed level, the Facility Management and Operations Program description details the specific key implementations and performance measures that encompass these day-to-day decisions. Tenant education is carried out in multiple formats. The Porcelain Press (example shown in Figure 2.3), Sustainability website, the Sustainability Program's quarterly newsletter Second Nature, Sustainability Program YouTube videos, and PNNL Insider newsletter all work to deliver important sustainability messages to Laboratory employees.

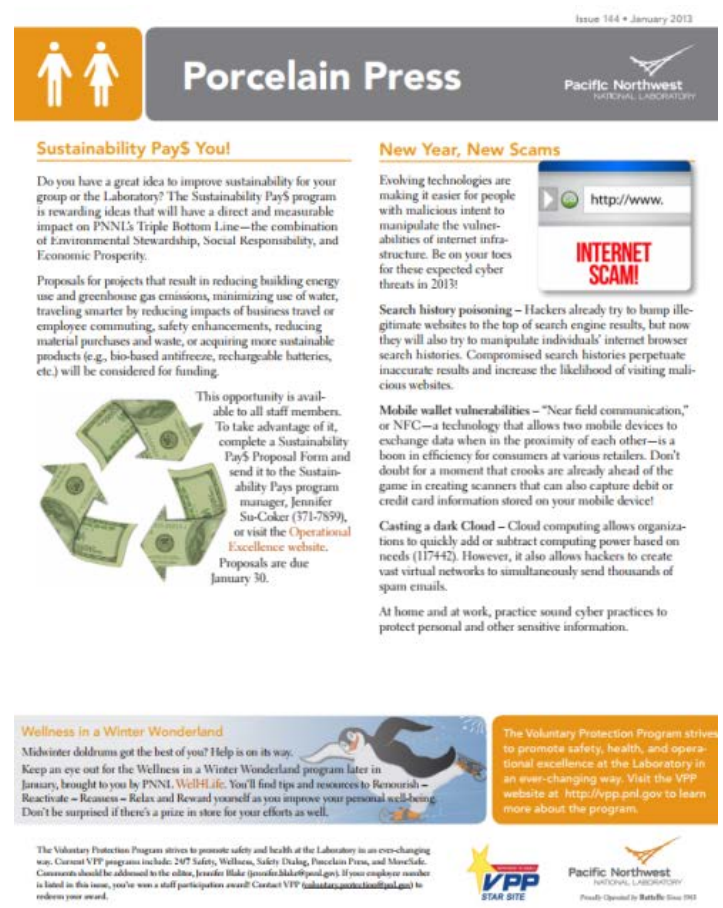

Figure 2.3. Example of the Porcelain Press Newsletter 


\subsubsection{Requirement 5}

The fifth requirement asks us to "augment building operations and maintenance as needed using occupant feedback on work space satisfaction.” PNNL meets this requirement by conducting a customer satisfaction survey for the building occupants. Staff are asked to rate their satisfaction on a scale of one to five in the following areas:

- building interior

- building exterior

- immediate office and surroundings

- halls and lobbies

- restrooms

- laboratory and/or shop areas

- $\quad$ walls, ceilings, and floors

- elevators

- parking lots

- grounds

- facility temperature

- facility lighting
- grounds lighting

- $\quad$ safe parking lots

- physical security of your workplace

- safety of your work place

- process for obtaining facility services (e.g., ESR)

- quality and timeliness of facility services

- Battelle Mail service (i.e., pick-up and delivery)

- $\quad$ walk-up copier locations

- walk-up copier reliability

- Central Duplicating Services

- conference room audio visual equipment

- conference room availability

- walkways during inclement weather (snow/ice)

The following chart in Figure 2.4 plots survey results for RPL in 2006, 2007, 2008, 2009, and 2011, as well as showing the median of all PNNL buildings in 2011. Supporting documentation in spreadsheet format can be made available upon request. 


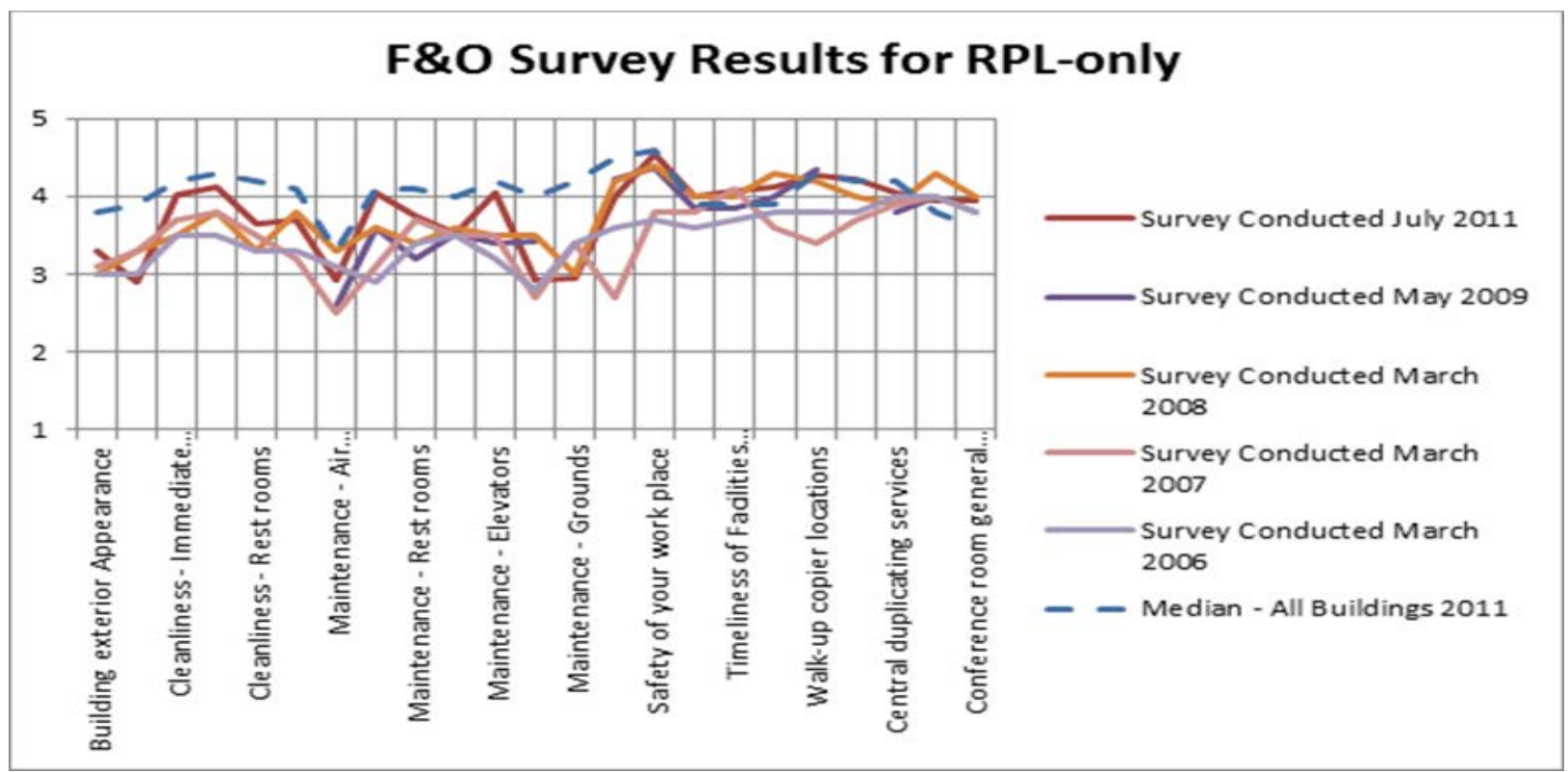

Figure 2.4. F\&O Survey Results for RPL-Only

\subsection{Commissioning}

This Guiding Principle requires that recomissioning tailored to the size and complexity of the building and its system components be performed within the last 4 years. In 2008 and 2009, PNNL contracted with Johnson Controls to perform a complete engineering and energy survey of the RPL site. In their final report, Johnson Controls recommended energy conservation measures aimed at improving comfort, safety, and reliability, as well as reducing energy consumption and emissions. Energy conservation measures identified in the final report resulted in projects to revamp and utilize the heat recovery system; cooling system improvements, including the installation of high efficiency chillers and additional cooling coils dedicated to the chilled water system; and the installation of LED exterior security lighting.

Commissioning at PNNL is proceduralized in F\&O Administrative Procedure ADM-142, Managing Sustainability Program Requirements. The 2007 Energy Independence and Security Act, (EISA) section 432 requires annual reporting to DOE on "Covered Facilities," those identified in the Facilities Information Management System (FIMS), which consume at least 75 percent of total FIMS facility usage. The RPL is one of PNNL's covered facilities. EISA requires that "Covered Facilities” undergo retrocommissioning every 4 years. Commissioning for the FY 2014 cycle at RPL is currently underway, with a scheduled submittal date of June 2014. 


\subsection{Guiding Principle Number Two}

\subsection{Energy Efficiency}

The second Guiding Principle deals with optimizing energy performance. The energy efficiency requirement reads as follows:

Energy Efficiency. Three options can be used to measure energy efficiency performance:

- Option 1: Receive an ENERGY STAR® rating of 75 or higher or an equivalent Labs21 Benchmarking Tool score for laboratory buildings,

- Option 2: Reduce measured building energy use by 20\% compared to building energy use in 2003 or a year thereafter with quality energy use data, or

- Option 3: Reduce energy use by 20\% compared to the ASHRAE 90.1-2007 baseline building design if design information is available. Use EnergyStar ${ }^{\circledR}$ and FEMP-designated Energy Efficient Products, where available.

The Energy Management Group at PNNL opted to pursue option two to meet this requirement. Using FY 2003 as a baseline, we compared total energy use with FY 2012, the most recently completed year. Combined energy use was compared by converting electricity and natural gas consumption to BTUs. Table 3.1 below details consumption and highlights the 24.51 percent energy reduction from the baseline year.

Table 3.1. 2003 and 2013 Comparison of Energy Consumption

\begin{tabular}{|c|c|c|c|c|c|c|}
\hline & \multicolumn{2}{|c|}{ Electricity in $\mathrm{kWh}$} & \multicolumn{2}{|c|}{$\begin{array}{l}\text { Natural Gas in } \\
\text { Therms }\end{array}$} & \multicolumn{2}{|c|}{$\begin{array}{c}\text { Combined Elect and } \\
\text { NG in BTU }\end{array}$} \\
\hline & FY 2003 & FY 2012 & FY 2003 & FY 2012 & FY 2003 & FY 2012 \\
\hline October & 644,080 & 562,315 & 18,549 & 3,563 & $4.05 E+09$ & $2.27 \mathrm{E}+09$ \\
\hline November & 633,456 & 610,344 & 29,007 & 14,498 & $5.06 \mathrm{E}+09$ & $3.53 E+09$ \\
\hline December & 660,746 & 670,865 & 34,494 & 23,156 & $5.70 \mathrm{E}+09$ & $4.60 \mathrm{E}+09$ \\
\hline January & 667,740 & 671,088 & 33,285 & 21,367 & $5.61 \mathrm{E}+09$ & $4.43 E+09$ \\
\hline February & 596,198 & 612,132 & 29,673 & 14,210 & $5.00 \mathrm{E}+09$ & $3.51 E+09$ \\
\hline March & 635,822 & 615,288 & 20,944 & 17,244 & $4.26 \mathrm{E}+09$ & $3.82 E+09$ \\
\hline April & 593,712 & 560,592 & 12,650 & 8,674 & $3.29 \mathrm{E}+09$ & $2.78 E+09$ \\
\hline May & 651,520 & 572,582 & 7,443 & 3,485 & $2.97 \mathrm{E}+09$ & $2.30 \mathrm{E}+09$ \\
\hline June & 726,408 & 561,528 & 1,859 & - & $2.66 \mathrm{E}+09$ & $1.92 \mathrm{E}+09$ \\
\hline July & 837,446 & 650,330 & 1,413 & - & $3.00 \mathrm{E}+09$ & $2.22 \mathrm{E}+09$ \\
\hline August & 771,752 & 658,292 & 1,461 & - & $2.78 \mathrm{E}+09$ & $2.25 \mathrm{E}+09$ \\
\hline September & 709,999 & 553,680 & 2,439 & - & $2.67 \mathrm{E}+09$ & $1.89 \mathrm{E}+09$ \\
\hline Total & $8,128,879$ & 7,299,036 & 193,217 & 106,197 & $4.71 \mathrm{E}+10$ & $3.55 \mathrm{E}+10$ \\
\hline \% Reduction & & $10.21 \%$ & & $45.04 \%$ & & $24.51 \%$ \\
\hline
\end{tabular}




\subsection{On-Site Renewable Energy}

This Guiding Principle requires that on-site renewable energy projects be implemented on agency property, for agency use, when lifecycle cost effective. Pacific Northwest National Laboratory has implemented a photovoltaic (PV) array that fulfills this requirement. The $125 \mathrm{~kW}$ PV array, pictured in Figure 3.1 below, produced 189.8 MWh of electricity in FY 2012, providing power to the Environmental Molecular Science Laboratory (EMSL), including a super-computing facility and adjacent car charging stations. Solar power generated is fully metered, and Lab employees can access a graphic indicating realtime generation and statistics.

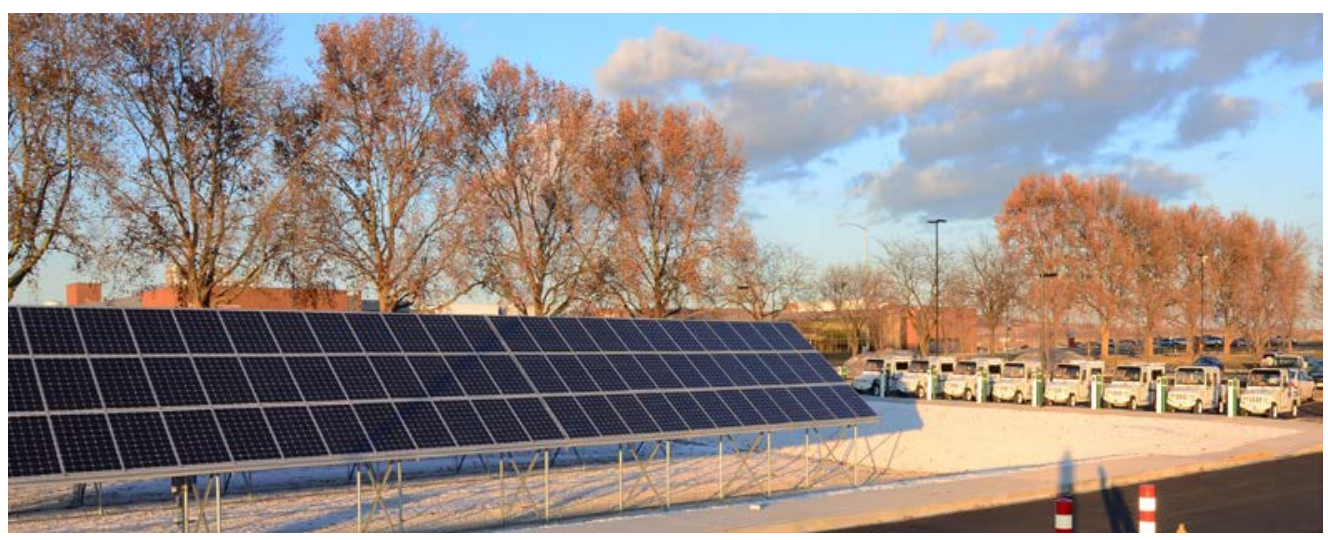

Figure 3.1. EMSL Photovoltaic Array

Another renewable energy project on the PNNL site is a solar hot water heater, installed in 2012 (see Figure 3.2). The unit, located on the roof of EMSL, produces approximately 160,000 BTU/hr of hot water.

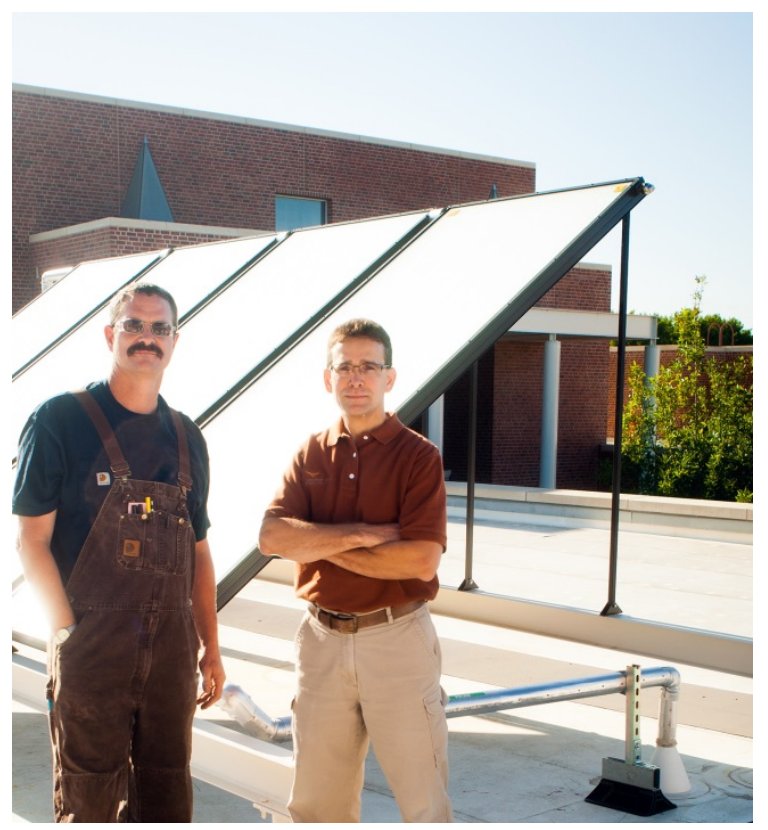

Figure 3.2. EMSL Solar Hot Water Heater 


\subsection{Measurement and Verification}

The requirement for measurement and verification is to "install building level electricity meters to track and continuously optimize performance.” The section goes on to require natural gas and steam meters where natural gas and steam are used.

Electricity is supplied to RPL from three services. The services supply normal power, standby power, and power to the chiller pad. Each of these services is metered. Meters generate a pulse based on consumption that is received by the Johnson Controls Metasys facility monitoring and control system (FMCS). Data tables and trends are available to be viewed by accessing the Metasys server or through the Decision Support for Operations and Maintenance (DSOM) system. DSOM collects metering data across the campus and serves it up using interactive displays available to all employees. A trend example for total electricity consumption at RPL is shown in Figure 3.3 below. No steam is delivered from outside the RPL complex, alleviating the need for steam meters. While RPL does use steam, the boiler producing steam is on-site, and the natural gas used to produce the steam is included in the building's energy total.

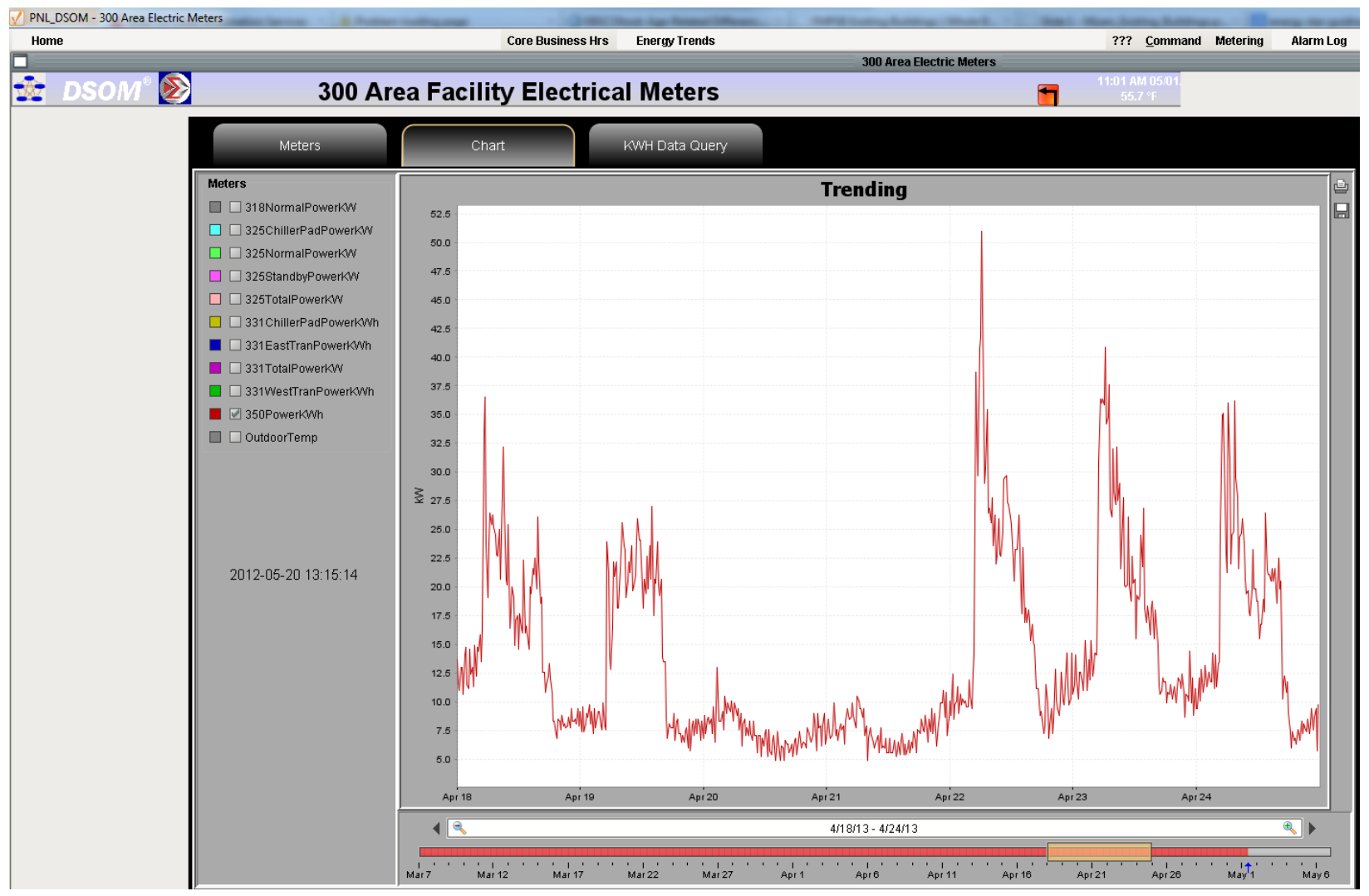

Figure 3.3. 300 Area Facility Electrical Meters 


\subsection{Benchmarking}

The Guiding Principle for benchmarking requires us to, "Compare annual performance data with previous years' performance data....” PNNL meets this requirement by collecting electricity, gas, and water data in a "Campus Energy Consumption" spreadsheet, which can be made available upon request. This data is maintained through a partnership with the Energy and Environmental Directorate, a research organization within PNNL. Monthly meetings are held to discuss benchmarking goals, perform trend analysis, and identify opportunities for energy savings. Meetings are conducted in the newly constructed Building Operations Control Center, a state-of-the-art asset capable of displaying multiple trends simultaneously on oversize wall monitors and accessing real-time data. Attendees at these meetings typically include the building manager, one or more building engineers, the PNNL campus energy manager, and a sustainability engineer. Graphics are frequently used to illustrate benchmarking results and track progress towards energy goals. A "Plan B Performance” file exists, which contains trends used in the April benchmarking meeting, and can be made available upon request. Examples of the trends used in benchmarking analysis are also included in Figures 3.4, 3.5, and 3.6 below.

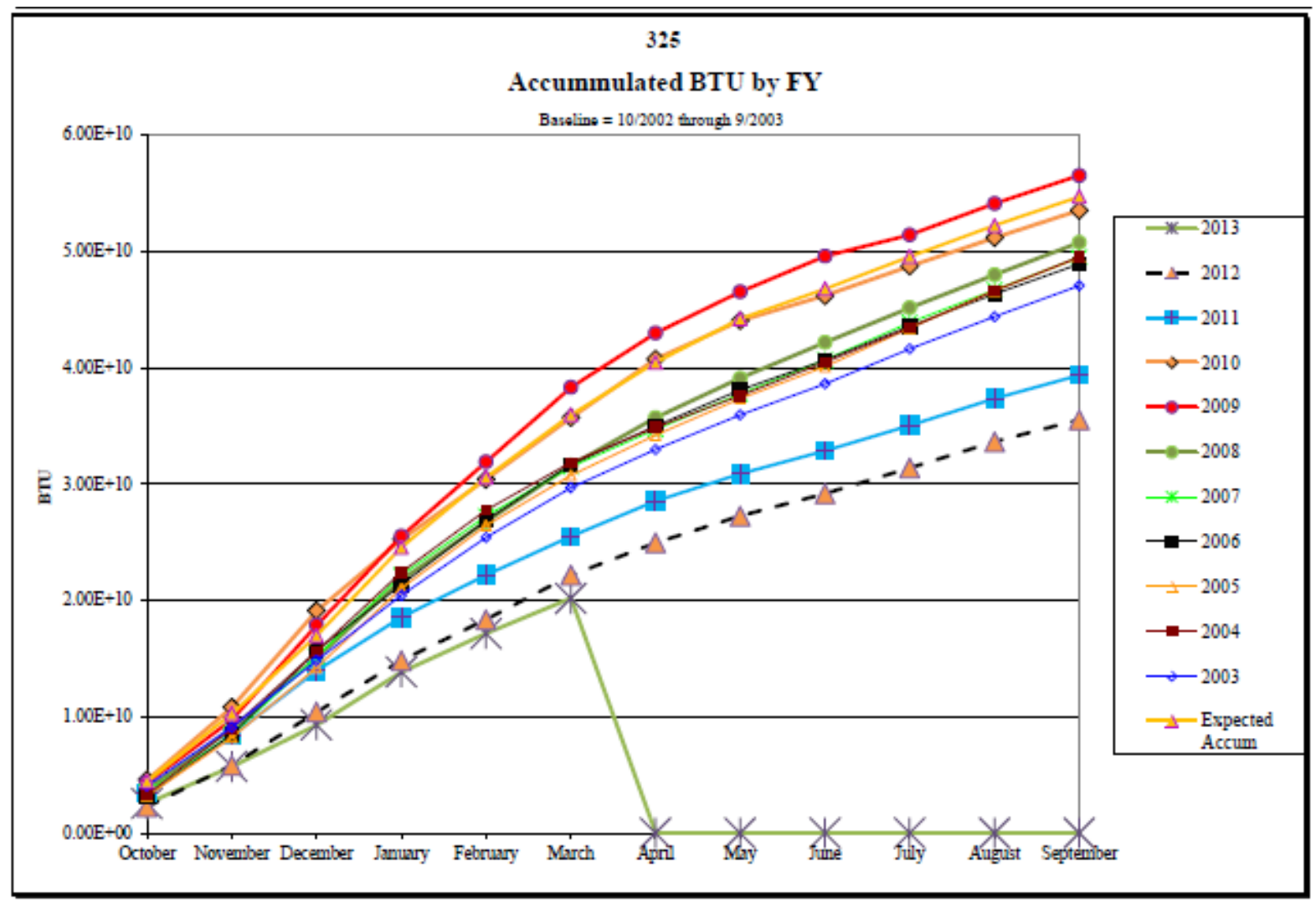

Figure 3.4. Accumulated BTU by FY 


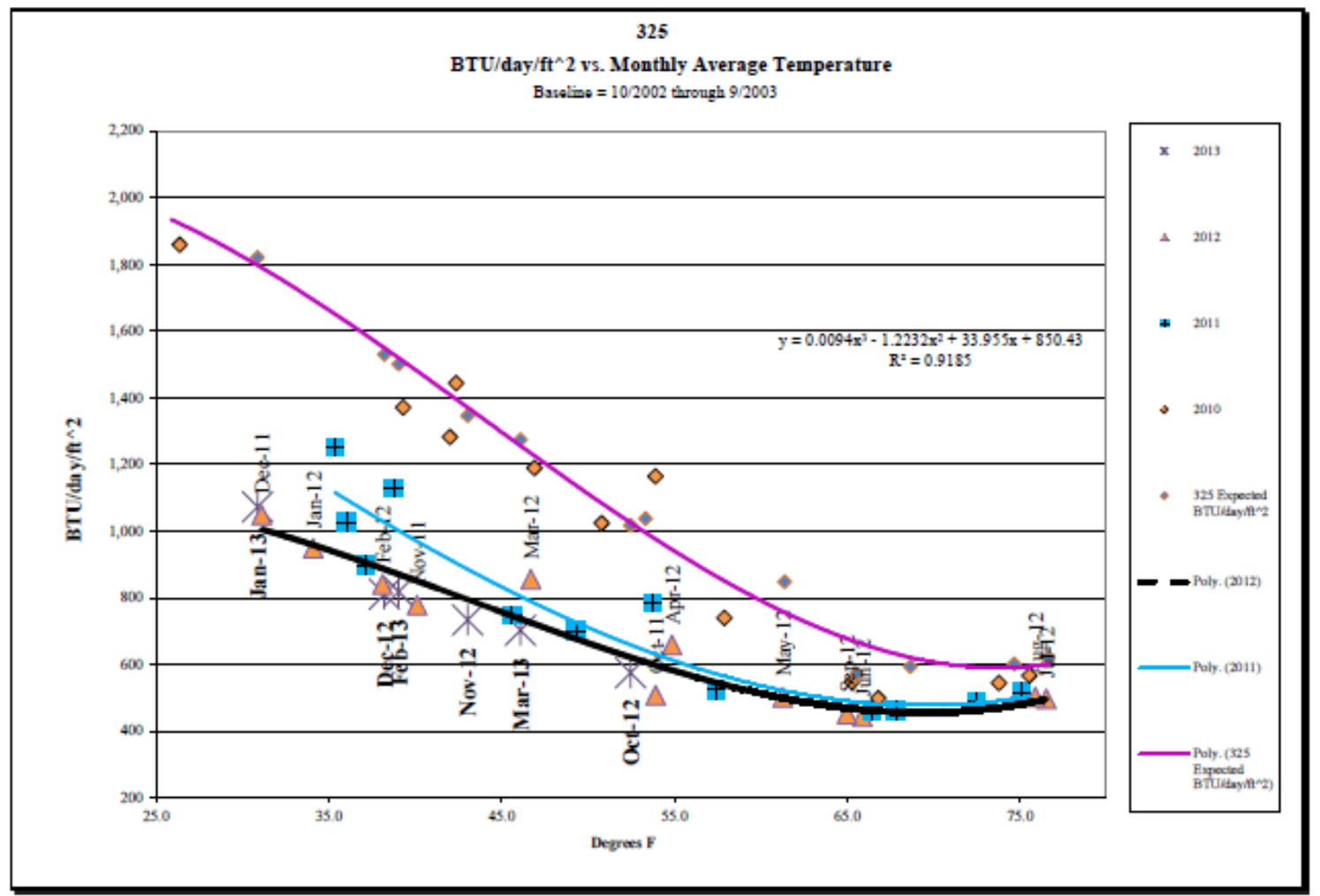

Figure 3.5. BTU/Day/Ft ${ }^{2}$ vs. Monthly Average Temperatures

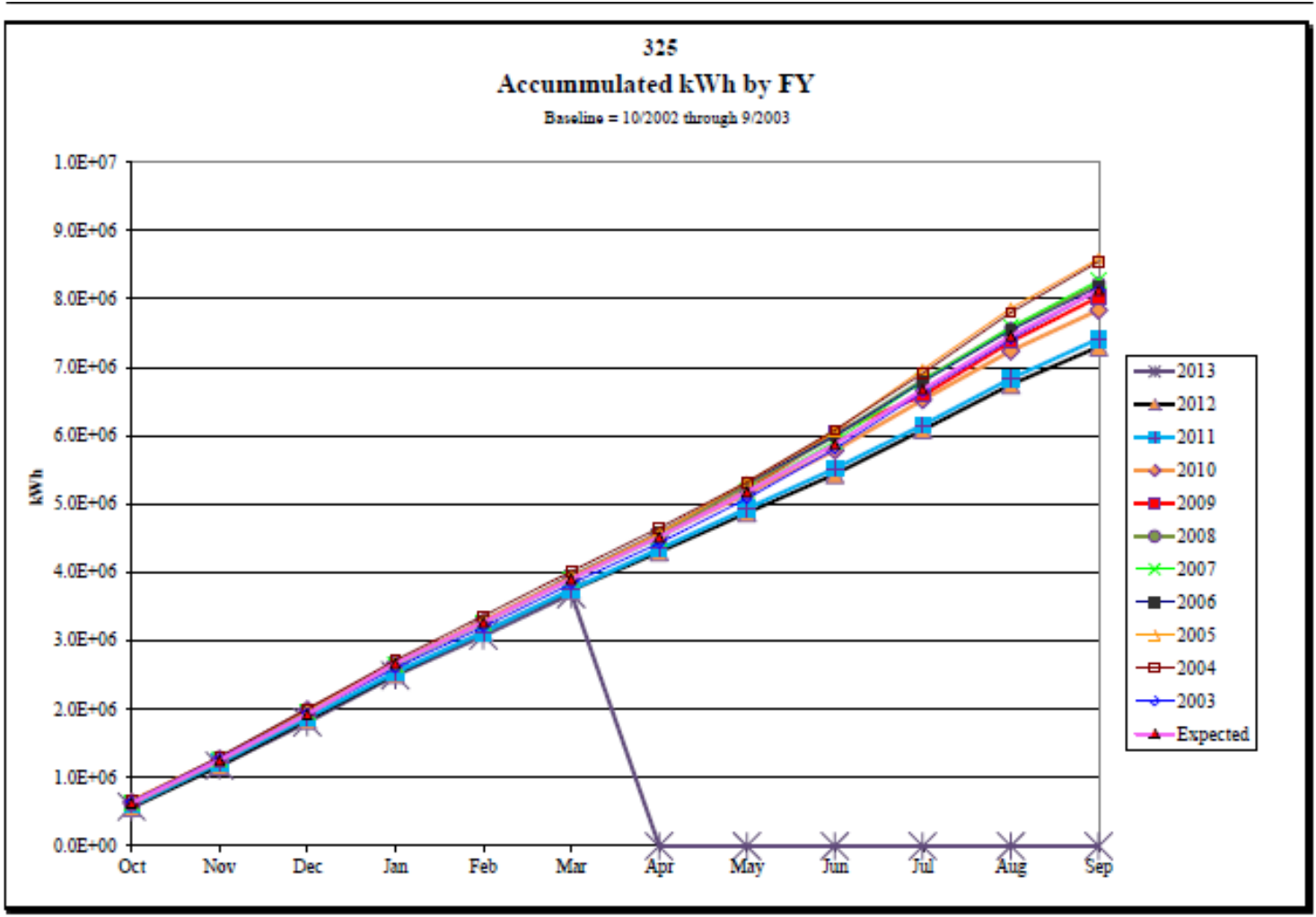

Figure 3.6. Accumulated kWh by FY 


\subsection{Guiding Principle Number Three}

\subsection{Indoor Water}

The requirements for Guiding Principle Number Three - Indoor Water allow for two options to be used to measure indoor potable water use performance. Those options read as follows:

- Option 1: Reduce potable water use by 20\% compared to a water baseline calculated for the building. The water baseline, for buildings with plumbing fixtures installed in 1994 or later, is $120 \%$ of the Uniform Plumbing Codes 2006 or the International Plumbing Codes 2006 fixture performance requirements. The water baseline for plumbing fixtures older than 1994 is 160\% of the Uniform Plumbing Codes 2006 or the International Plumbing Codes 2006 fixture performance requirements, or

- Option 2: Reduce building measured potable water use by 20\% compared to building water use in 2003 or a year thereafter with quality water data.

The PNNL Energy Management team decided to pursue option two to demonstrate the required reduction in water use at RPL. Three water meters were installed during FY 2006 to measure the total water use. FY 2007 was the first full year of water data available and is being used as the baseline year. Collected data is listed and graphically displayed in Table 4.1 and Figure 4.1 below.

Table 4.1. 235 Water Consumption (CCF)

\begin{tabular}{lr} 
FY 2007 & 2,630 \\
FY 2008 & 2,460 \\
FY 2009 & 2,280 \\
FY 2010 & 2,500 \\
FY 2011 & 1,090 \\
FY 2012 & 674 \\
\hline Total Reduction & $74 \%$
\end{tabular}

\section{Water Consumption (CCF)}

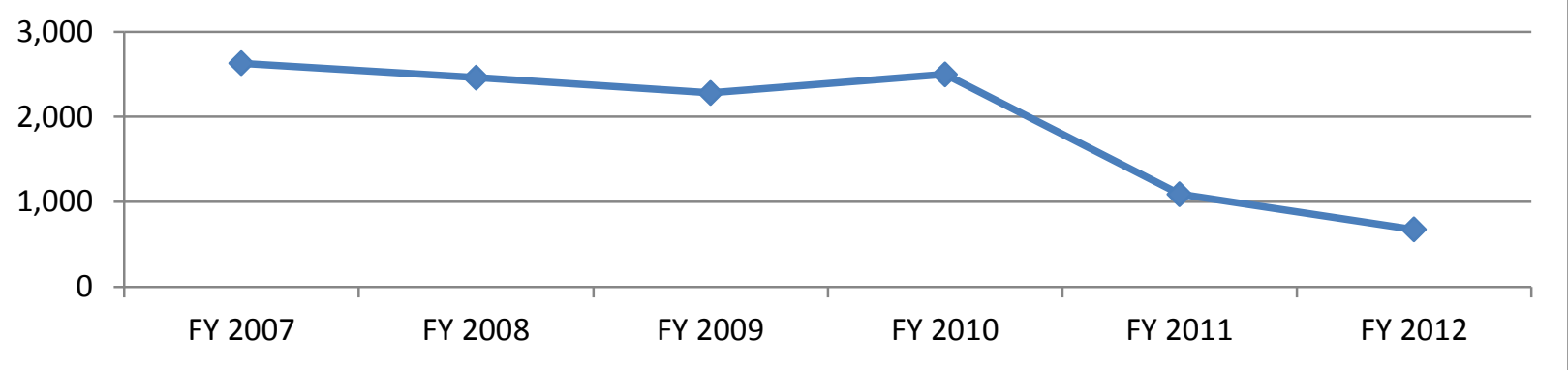

Figure 4.1. 325 Water Consumption 


\subsection{Outdoor Water}

The requirements for Guiding Principle Number Three - Outdoor Water allow for three options to be used to measure indoor potable water use performance. Those options read as follows:

- Option 1: Reduce potable irrigation water use by 50\% compared to conventional methods, or

- Option 2: Reduce building related potable irrigation water use by 50\% compared to measured irrigation water use in 2003 or a year thereafter with quality water data, or

- Option 3: Use no potable irrigation water.

The PNNL Energy Management team opted to use option three to demonstrate compliance with this principle. The RPL uses no potable water for irrigation. The facility does not have any grass or landscaping, so no water, potable or otherwise, is consumed for this purpose (see Figure 4.2).

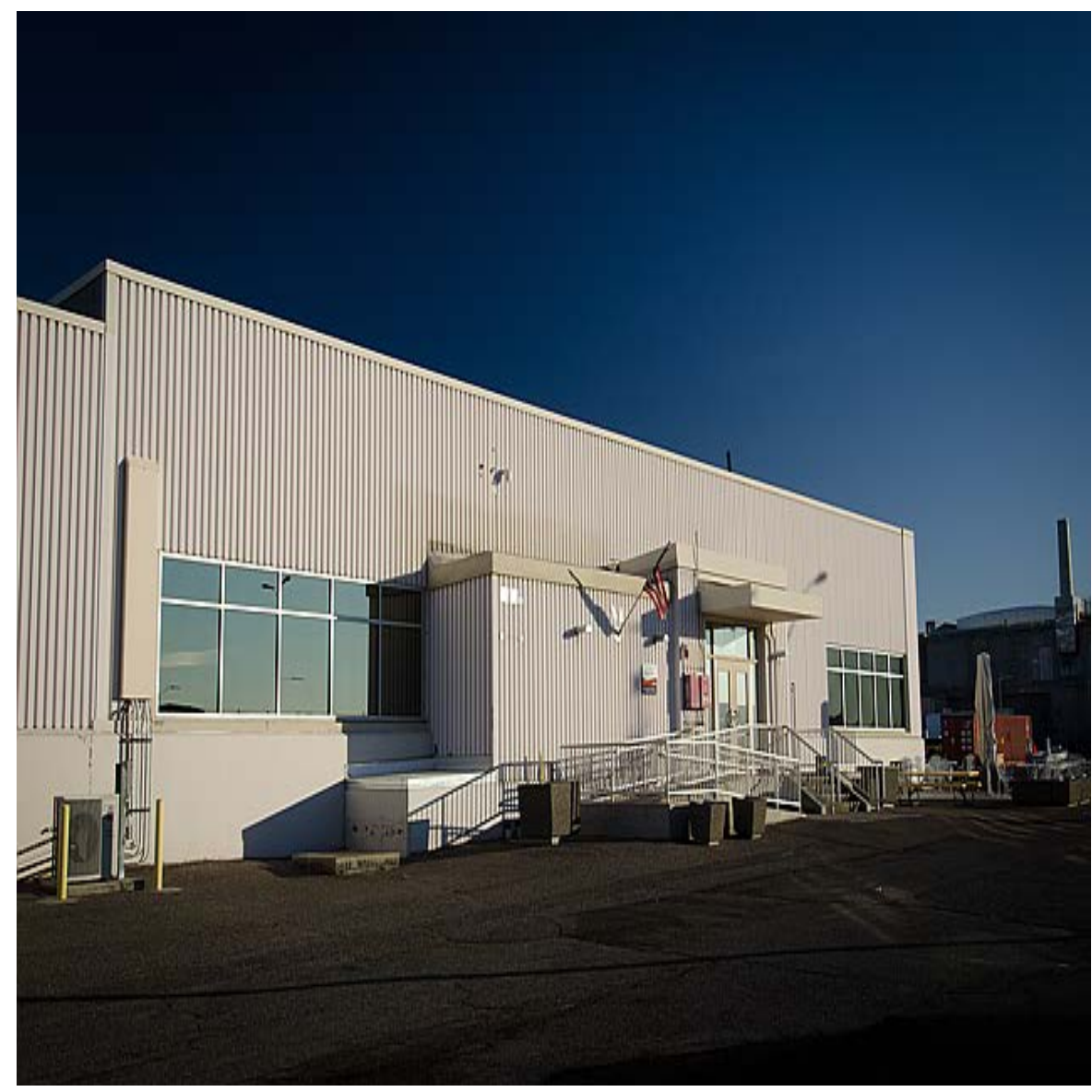

Figure 4.2. Outside View of RPL 


\subsection{Measurement of Water Use}

This Guiding Principle requires the installation of water meters for buildings with significant indoor and outdoor water use and the demonstration of a 20 percent reduction in their combined indoor and outdoor water use. This Guiding Principle also requires us to employ strategies that reduce storm water runoff and discharges of polluted water offsite.

The RPL staff installed three Onicon insertion turbine type meters in 2006 that measure the combined total of water use at the facility. These meters generate a pulse that is received by the Johnson Controls Metasys FMCS. Data tables and trends are available to be viewed by accessing the Metasys server or through the DSOM system. DSOM collects metering data across the campus and serves it using interactive displays available to all employees. A trend example retrieved from the Metasys system for potable water use at RPL over a 24-hour period is shown in Figure 4.3 below.

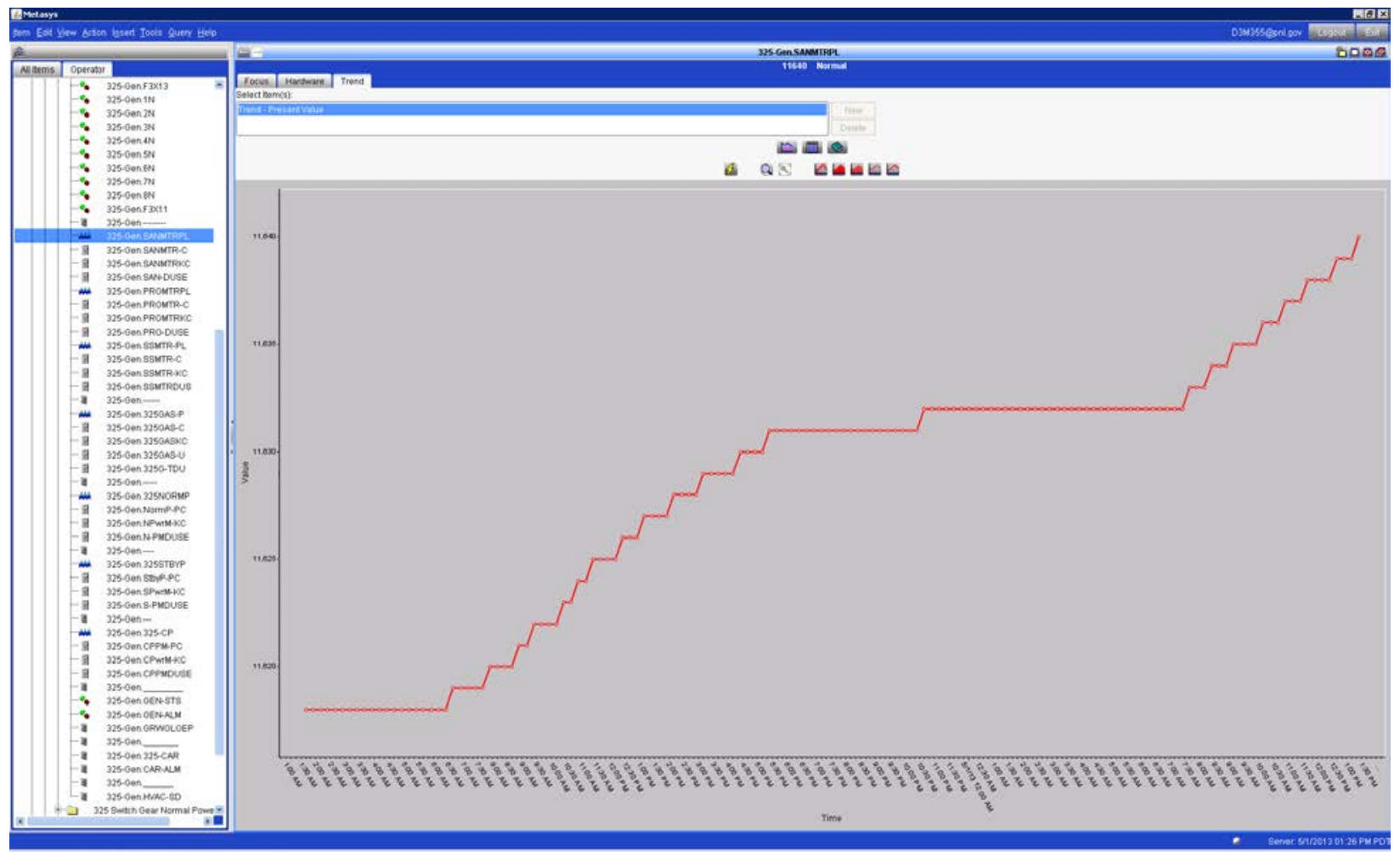

Figure 4.3. Metasys System Trend Example for Potable Water Use at RPL

Aside from being a Guiding Principle requirement, metering at RPL and all PNNL buildings is a contract deliverable requirement to DOE. Additional metering details, including our metering strategy and progress across the campus, are detailed in the 2012 PNNL Metering Plan: Monitoring Energy and Potable Water Use in PNNL EMS4 Buildings.

The water reduction goal has been achieved using a baseline year of 2007, the first year with metered water data. No outdoor water is consumed at RPL, so the indoor reduction totals (and, therefore, combined totals) are detailed in section 4.1, Indoor Water. A total measured reduction of 74 percent from the baseline year fulfills the requirement. 
The RPL has employed strategies that have eliminated storm water runoff and the discharge of polluted water offsite. Redevelopment work at RPL is engineered using PNNL F\&O process guide ADM-CM-057. The process guide requires storm water runoff from all buildings and all parking areas to be collected and disposed of on-site, with a combination of surface swales, underground infiltration beds (or percolation beds), and dry wells.

\subsection{Process Water}

This Guiding Principle requires lifecycle cost-effective water conservation measures be taken when potable water is used to improve a building's energy efficiency.

The RPL does not have a cooling tower and uses very little potable water to improve building energy efficiency. The sole example is the use of evaporative cooling on RPL supply fan number five to cool the men's change room and the Plutonium conference room. Supply fan number five is scheduled for removal this year. Upon removal, no potable water will be used to improve building energy efficiency.

The conservation measures currently taken include:

- $\quad$ recirculating unevaporated water

- $\quad$ eliminating bleed-off water

- the installation of an outside air filter installed upstream of the unit to keep the pads clean and reduce pressure drop across them.

\subsection{Water-Efficient Products}

This Guiding Principle requires us to use the U.S. Environmental Protection Agency's (EPA's) WaterSense-labeled products or other water conserving products, where available. It also requires us to choose irrigation contractors who are certified through a WaterSense-labeled program.

PNNL chooses WaterSense-labeled products as part of the overall water reduction strategy at RPL. Zurn's “The Pint” 0.125 gallon per flush, ultra-low consumption urinal systems were installed in men's restrooms. Low flow faucets equipped with motion sensors were installed at restroom sinks. Examples of water-efficient products installed at PNNL are shown in Figure 4.4. PNNL F\&O process guide ADMCM-057 requires the use of WaterSense-labeled or other water conserving products for future renovations or fixture replacements. 


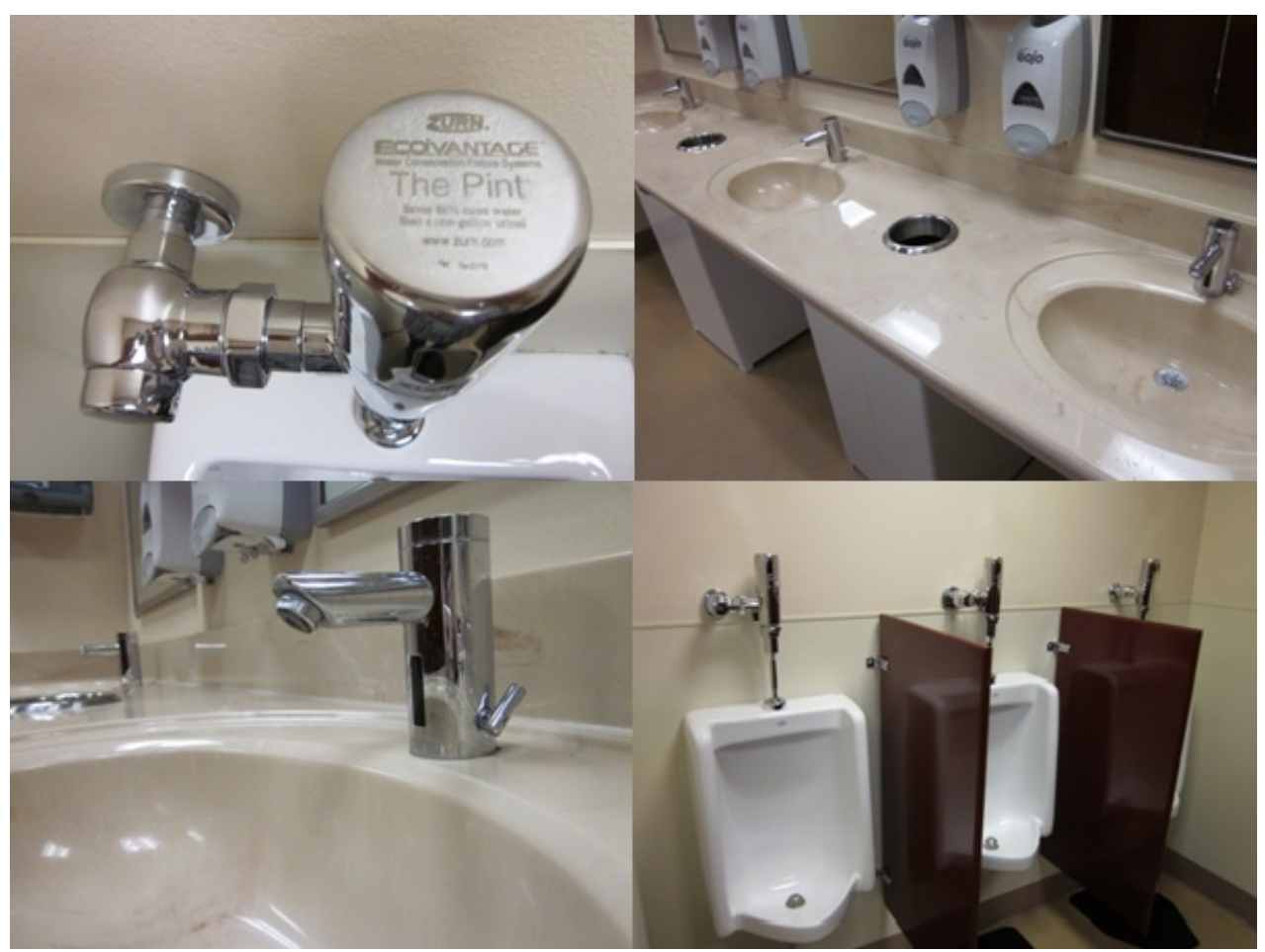

Figure 4.4. Water-Efficient Products Installed at RPL 


\subsection{Guiding Principle Number Four}

\subsection{Ventilation and Thermal Comfort}

This Guiding Principle requires us to meet American Society of Heating, Refrigerating, and AirConditioning Engineers (ASHRAE) Standard 55-2004, Thermal Environmental Conditions for Human Occupancy and ASHRAE Standard 62.1, Ventilation for Acceptable Indoor Air Quality.

We began the process of validating that RPL met ASHRAE 55 by taking the first round of prescribed measurements in the standard. We selected 10 spaces within the building that represented a good cross section of occupied spaces - some spaces with exterior walls, some without exterior walls, and evenly spread throughout the building. The initial measurements included temperatures at the work locations within the spaces, floor, ceiling, and wall temps, and air velocity measurements using a portable anemometer. After analyzing the temps, we realized the space temperature was not under the influence of wall, ceiling, or floor temps, and there was no measurable air velocity, so no adjustments were needed per the adjustment calculation in the standard.

We concluded that temperature measurements gathered using our existing temperature sensors throughout the building could offer reliable data and much more of it. While the ASHRAE standard considers two snap-shots in time, one in the heating season and one in the cooling season, we devised a way to consider temperatures throughout every work day during the entire year using our existing extensive temperature database. We selected 10 sensors in occupied work spaces throughout the building. We then analyzed the readings taken every 15 minutes over the course of a year and compared them to the temperature band in the psychometric chart in the standard. Using this method we were able to determine that all of the spaces analyzed in RPL exhibited acceptable thermal environmental conditions. An example of this method is shown in Figure 5.1 below.

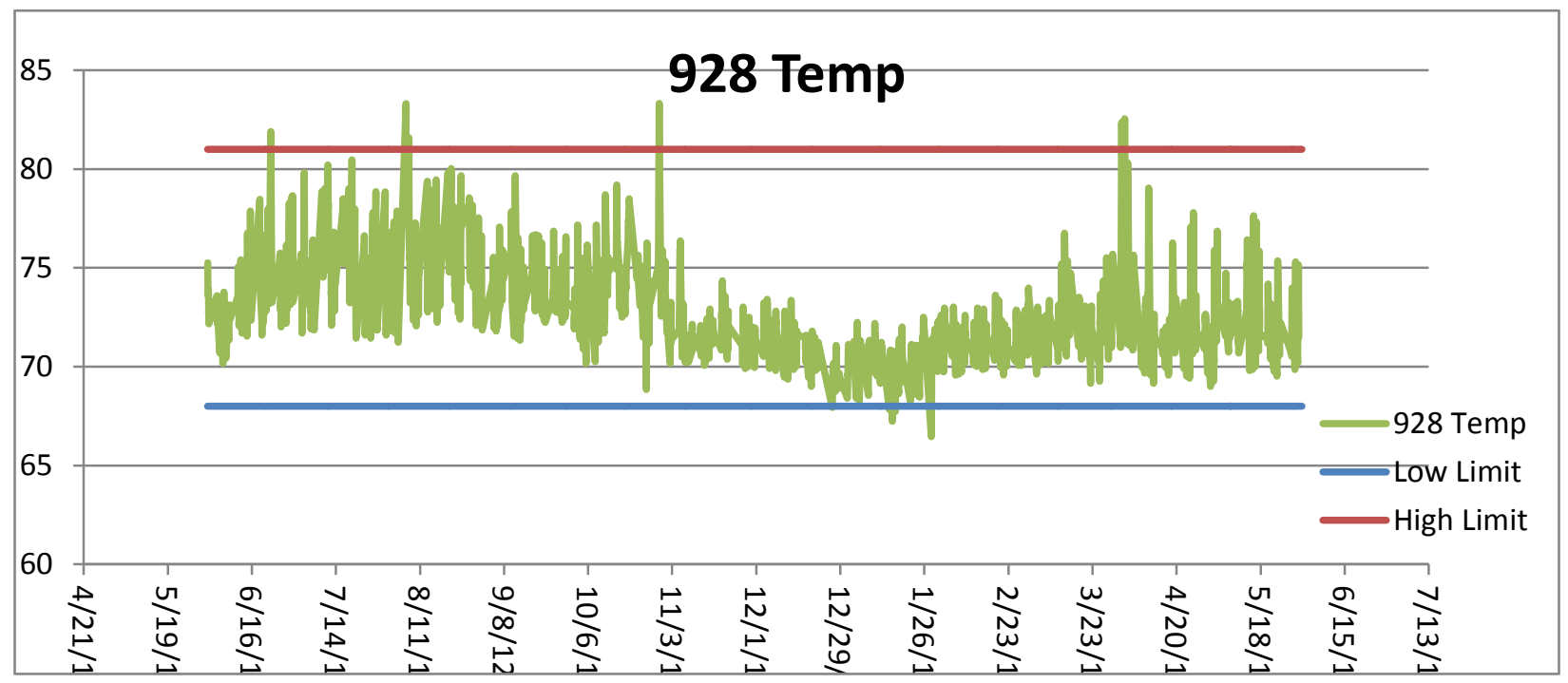

Figure 5.1. Sample Trace Showing 1 Year of Temperature Data in RPL Room 928

An analysis on the RPL ventilation system based on ASHRAE 62.1-2007 was performed in 2013. The report indicating compliance with this standard, ASHRAE 62.1-2007 Analysis Report, is available upon request. 


\subsection{Moisture Control}

This Guiding Principle requires us to provide policy and illustrate the use of an appropriate moisture control strategy to prevent building damage, minimize mold contamination, and reduce health risks related to moisture. For façade renovations, Dew Point analysis and a plan for cleanup or infiltration of moisture into building materials are required.

PNNL F\&O process guide ADM-CM-057 discusses engineering design requirements across the PNNL campus. This guide details requirements for moisture control in renovations and specifics on how to address moisture infiltration into a building.

Building engineering and operations staff at RPL implement a multi-faceted moisture control strategy aimed at preventing building damage, minimizing mold contamination, and reducing health risks related to moisture. Periodic maintenance (PM) practices performed at different times throughout the year, power operator rounds performed throughout the day, and on-site engineering support and supervision all work together to deliver moisture control.

The PM program at RPL automatically schedules work orders at specific frequencies, based on typical and historic information. Roof drains, downspouts, and gutters are cleaned twice per year and documented on PM-1917. Heat tracing is used to prevent ice buildup in the roof drain system, driving moisture inside the building. PMs are used to generate the work order that energizes the heat tracing in the winter and de-energizes it in the spring. Vent and sewer trap checks are performed monthly and documented on PM-4539. The sump pump that serves the retention process sewer is important for moisture control and is examined monthly through PM-64009.

The RPL benefits from operator support around the clock. Two different rounds are performed daily, one by the shift operator and one by the tour operator. SOP-325-RND-01, 325 Operator Rounds details each of these rounds. Moisture control is an important piece of the visual observation by the power operators. Some specific round requirements include looking for water accumulation, looking for leakage, and checking backflow preventers for water in the collection pan.

The third piece of the moisture control strategy at RPL involves the highly trained engineering team located in and dedicated to this facility. The engineering team leads the way in identifying and implementing moisture control opportunities. The RPL is equipped with an asphalt roof that is inspected by staff engineers and a PNNL architect, periodically. These inspections have resulted in repairs to the roof in 2010 and in 2012, as well as a new roof being installed on the filter building. A recent project installed pipe insulation on chilled water lines, preventing the buildup of moisture due to condensation. A project performed in the summer of 2012 examined the preheat system for leaks and made repairs as discovered. A similar project currently underway is examining the reheat system for leaks and also making repairs.

\subsection{Daylighting and Lighting Controls}

This Guiding Principle requires that automated lighting controls, such as occupancy/vacancy sensors with manual-off capability are provided for appropriate spaces including restrooms, conference and meeting rooms, employee lunch and break rooms, training classrooms, and offices. Additionally it 
requires that either a 2 percent daylighting factor is achieved or that 50 percent of regularly occupied spaces have occupant-controlled lighting that allows adjustments to suit individual task needs.

While some perimeter offices in RPL take advantage of daylighting, the design of the building does not lend itself to increasing the percentage of space that meets the daylight factor requirement. Instead, we chose to satisfy this requirement using occupant-controlled lighting levels and occupancy sensors in appropriate spaces.

Occupant-controlled lighting level is achieved in RPL primarily by dimmers and by the existing circuiting of lights that does not turn off all lights within a space using a single switch. A space-by-space lighting survey was conducted in early 2013 of the 261 spaces within RPL. Results confirmed that 68 percent of spaces have multiple lighting levels available.

The same lighting survey looked at the number of appropriate spaces that had existing occupancy sensors. As a result of the survey and this Guiding Principle effort, a project was initiated to install an additional 95 occupancy sensors in 74 spaces throughout the building. Space types that received the new occupancy sensors included restrooms, conference rooms, lunch and break rooms, and offices. After completing the installation of these sensors, RPL now meets the requirement outlined in this Guiding Principle.

\subsection{Low-Emitting Materials}

This Guiding Principle requires us to use low-emitting materials for building modifications, maintenance, and cleaning. In particular, we must specify the following materials and products to have low pollutant emissions: composite wood products, adhesives, sealants, interior paints and finishes, solvents, carpet systems, janitorial supplies, and furnishings.

PNNL complies with this Principle in each of its buildings, including RPL. The PNNL Green Housekeeping Policy, available upon request, outlines the Lab’s holistic approach to facility cleaning, going beyond appearances to focus on health and environmental impacts. The policy implementation details the product standards given preference when purchasing and using cleaning and floor service products. These standards include:

- Green Seal Standard GS-37 (www.greenseal.org)

- where GS-37 is not applicable, California Code of Regulations maximum allowable volatile organic compound (VOC) levels (www.calregs.com)

- Carpet and Rug Institute Seal of Approval requirements for spot removers and pre-spray/ intank cleaning solutions.

In addition to the Green Housekeeping Policy, low-emitting purchasing is required as a part of PNNL's sustainable acquisitions program, which embeds the purchase of low-emitting material within the contracting and ordering process. The Environmental Protection and Regulatory Programs Division at PNNL discusses these and other procurements on its Sustainable Acquisition webpage. The Pollution Prevention Pays Program at PNNL is used to help implement concepts or ideas to reduce environmental impacts and create efficiencies in operations. After evaluating solvents, program members were able to 
replace Trichloroethylene solvent used as a degreaser with a non-halogenated solvent and still obtain acceptable performance. PNNL Acquisition Guideline 24, "Sustainable Acquisitions" requires purchasing decisions for designated products to be consistent with the guidelines it sets. Designated products and guidance specific to this Guiding Principle include:

- composite wood products that contain no added urea-formaldehyde resins

- adhesives and sealants that comply with South Coast Air Quality Management Rule \#1168, as well as with VOC limits specified in the guideline

- interior paints and finishes that comply with the appropriate Green Seal Standard

- $\quad$ carpet systems that comply with the Carpet and Rug Institute Green Label Plus Program

- furnishings that are Greenguard Indoor Air Quality certified.

\subsection{Integrated Pest Management}

This Guiding Principle requires the use of integrated pest management techniques, as appropriate, to minimize pesticide usage. It also requires PNNL to use EPA-registered pesticides only when needed.

As stated in the FY 2013 Site Sustainability Plan: An Authentic Commitment, PNNL has statelicensed, private commercial pesticide applicators on the grounds crew who are required annually to complete continuing education classes to learn about the latest trends in pest control, current chemical and biological control agents, and updated legislative changes. All applicators are committed to integrated pest management (IPM) principles, where appropriate. PNNL grounds staff recognizes the responsibility to provide a clean, low-pest environment at the Laboratory, and also strives to limit control efforts to those absolutely required for optimal results. Pest control methods begin with the lowest impact, escalating when required and only to the level necessary for acceptable control. Examples of IPM best practices include:

- using wasp traps in lieu of spraying, when appropriate

- good housekeeping by removing cardboard and unwanted wood pallets in yards and storage areas to prevent pest nesting

- $\quad$ using sticky and metal traps for mice control

- $\quad$ using netting and spikes, when possible, to reduce bird droppings.

\subsection{Environmental Smoke Control}

The Guiding Principle that includes Environmental Smoke Control prohibits smoking within the building and within 25 feet of all building entrances, operable windows, and building ventilation intakes.

PNNL has implemented a set of "Basic Staff Practices." This work control includes the basic requirements and considerations for being employed by PNNL, as well as for work activities in PNNL- 
operated work environments. Within the Staff Responsibilities and Limitations, Security Requirements, and use of PNNL Facilities section lies the following requirement:

- Do not smoke inside any building or within 25 feet from building entrances, exits, windows that open, and ventilation intakes that serve a building. 


\subsection{Guiding Principle Number Five}

\subsection{Recycled Content}

The Recycled Content requirement reads as follows:

Per Section 6002 of the Resource Conservation and Recovery Act (RCRA) (PDF), for EPA-designated products, use products meeting or exceeding EPA's recycled content recommendations for building modifications, maintenance, and cleaning. For other products, use materials with recycled content such that the sum of postconsumer recycled content plus one-half of the pre-consumer content constitutes at least 10\% (based on cost or weight) of the total value of the materials in the project. If EPA-designated products meet performance requirements and are available at a reasonable cost, a preference for purchasing them shall be included in all solicitations relevant to construction, operation, maintenance of or use in the building. EPA's recycled content product designations and recycled content recommendations are available on EPA's Comprehensive Procurement Guideline website.

PNNL has a mature sustainable acquisitions program that embeds the purchase of items containing recycled content within the contracting and ordering process. PNNL Acquisition Guideline 24:

Sustainable Acquisitions requires purchasing decisions for designated products to be consistent with the Environmental Protection Agency procurement guidelines. Exhibit 1 to Acquisition Guideline 24 dictates specific content requirements in nine categories; Office Products, Janitorial Products, Building Insulation, Construction Products, Landscaping Products, Park and Recreation Products, Transportation Products, Vehicular Products, and Miscellaneous Products.

As a resource, the procurement department has assigned a sustainable acquisitions subject matter expert (SME) to consult with when purchasing products containing recycled content. The SME ensures compliance with applicable requirements and guidelines, such as this Guiding Principle.

Compliance with Acquisition Guideline 24, section 3.0, "Recycled Content," is checked during the electronic procurement process in the E-Pro Risk Assessment Checklist. Purchasers must check the box associated with checklist item number twenty-two, indicating that purchase is consistent with recycled content requirements.

The Guiding Principle allows for exceptions to the recycled content requirement based on "reasonable cost.” The exception process at PNNL is detailed in Acquisition Guideline 24, section 2.4. Exceptions are requested by the technical oversight representative and evaluated by the sustainable acquisitions SME. Granted exceptions are documented in the contract as a modification of Clause 381, "Sustainable Acquisition Requirements," and the circumstances of the exception are addressed in the Memorandum of Procurement. 


\subsection{Biobased Content}

The Biobased Content requirement reads as follows:

Per Section 9002 of the Farm Security and Rural Investment Act (FSRIA), for USDAdesignated products, use products with the highest content level per USDA's biobased content recommendations. For other products, use biobased products made from rapidly renewable resources and certified sustainable wood products. If these designated products meet performance requirements and are available at a reasonable cost, a preference for purchasing them should be included in all solicitations relevant to construction, operation, maintenance of or use in the building. USDA's biobased product designations and biobased content recommendations are available on USDA's BioPreferred website.

PNNL has a mature sustainable acquisitions program that embeds the purchase of items containing biobased content within the contracting and ordering process. PNNL Acquisition Guideline 24, "Sustainable Acquisitions" requires purchasing decisions for designated products to be consistent with the U.S. Department of Agriculture (USDA) procurement recommendations. Exhibit 1, section 2, of Acquisition Guideline 24 dictates specific content requirements in 66 categories.

As a resource, the procurement department has assigned a sustainable acquisitions SME to consult with when purchasing products containing biobased content. The SME ensures compliance with applicable requirements and guidelines, such as this Guiding Principle.

Compliance with Acquisition Guideline 24, section 4.0, "Biobased Content,” is checked during the electronic procurement process in the E-Pro Risk Assessment Checklist. Purchasers must check the box associated with checklist item number 22, indicating that purchase is consistent with biobased content requirements.

The Guiding Principle allows for exceptions to the biobased content requirement, based on "reasonable cost." The exception process at PNNL is detailed in Acquisition Guideline 24, section 2.4. Exceptions are requested by the technical oversight representative and evaluated by the sustainable acquisitions SME. Granted exceptions are documented in the contract as a modification of Clause 381, "Sustainable Acquisition Requirements," and the circumstances of the exception are addressed in the Memorandum of Procurement.

\subsection{Environmentally Preferable Product}

Guiding Principle number five, Environmentally Preferable Product, requires us to use products that have a lesser or reduced effect on human health and the environment over their lifecycle when compared with competing products or services that serve the same purpose. PNNL has implemented policies and procedures aimed at meeting this requirement when purchasing goods and services at the Lab. PNNL Acquisition Guideline 24, “Sustainable Acquisitions," outlines Battelle's plan to comply with clause H-43 of its 1830 Contract, pertaining to the acquisition of environmentally preferable products and services and energy-efficient products, as required by the Federal Executive orders 13514 and 13423. 
The six main categories of environmentally preferable products are recycled content products, biobased products, energy-efficient products, water-efficient products, computer products registered with the EPA’s Electronic Product Environmental Assessment Tool (EPEAT), and non-ozone-depleting products. Most of these six product types are discussed elsewhere in this Guiding Principle document.

PNNL strives to purchase desktop and laptop computers and monitors that are registered with EPEAT, unless there is no standard for the product.

EPEAT is managed by the Green Electronics Council of the EPA. In 2012, PNNL purchased 835 desktop computers, 799 LCD monitors, and 691 laptop computers, all registered as EPEAT Gold. The Lab purchased an additional 14 LCD monitors registered as EPEAT silver and another 24 desktop and 37 laptop computers that were Energy Star qualified, but not EPEAT registered.

No computers or monitors were purchased that did not qualify for an Energy Star rating or EPEAT registration. By ordering computers through the PNNL managed hardware system, purchasers are able to ensure only computers meeting the Acquisition Guideline are procured.

\subsection{Waste and Materials Management}

The Waste and Materials Management Guiding Principle requires us to

...provide reuse and recycling services for building occupants, where markets or on-site recycling exist. Provide salvage, reuse and recycling services for waste generated from building operations, maintenance, repair and minor renovations, and discarded furnishings, equipment and property. This could include such things as beverage containers and paper from building occupants, batteries, toner cartridges, outdated computers from an equipment update, and construction materials from a minor renovation.

PNNL has a genuine commitment to pollution prevention and recycling. In 2012, PNNL donated or transferred 1,164 desktop computers, 548 laptop computers, and 444 LCD monitors, allowing for reuse rather than sending them to the landfill. Lab-wide, 1,825 metric tons of construction and demolition waste and debris was diverted from the landfill, leaving only 47 metric tons designated as landfilled waste. In the municipal solid waste category consisting of trash and organics generated by normal housekeeping activities, PNNL diverted 553 metric tons from the landfill, composted an additional 42 metric tons offsite, and composted another 1.2 metric tons on-site.

The RPL has reuse and recycling services available to all staff. Locations of RPL recycle locations are detailed in Table 6.1. Recycling services are available for aerosol cans, aluminum, tin, glass, plastic, batteries, cardboard, cell phones, compost, electronic media (CDs, video and cassette tapes, diskettes, etc.), eye glasses, hearing aids, hardbound books, paper, lamps, printer cartridges, office products and furnishings, wood, and more. Large bins for the recycling of metals are provided through a contract with local small business Twin City Metals. 
Table 6.1. RPL Recycle Locations

\begin{tabular}{|l|l|l|l|}
\hline 2 & 950 & Battery Buckets & Upstairs Lunchroom \\
\hline 1 & 205 & Battery Buckets & Instrument Shop \\
\hline 1 & 319 & Battery Buckets & Alkaline Only \\
\hline 1 & OUTSD & Cardboard Lugger & South of Building \\
\hline 2 & 950 & Catalog Bin & Upstairs Lunchroom \\
\hline 1 & CPM01 & Catalog Bin & 1st Floor Copy Room \\
\hline 1 & LUN01 & Electronic Media & Lunchroom \\
\hline 2 & 950 & Paper, Shred & Upstairs Lunchroom \\
\hline 1 & LUN01 & Plastic/Tin/Glass & Lunchroom \\
\hline 2 & 950 & Plastic/Tin/Glass & Upstairs Lunchroom \\
\hline 1 & LUN01 & Toner \& Cell Phone Recycling Bin & Lunchroom \\
\hline
\end{tabular}

Details on waste and materials management can be found in the PNNL Solid Waste Management Policy. This policy sets specific goals for waste diversion, reuse, and recycling. The policy also identifies the PNNL Pollution Prevention Program manager and Excess Material \& Redeployment manager.

\subsection{Ozone Depleting Compounds}

This Guiding Principle requires us to eliminate the use of ozone depleting compounds where alternative environmentally preferable products are available, consistent with either the Montreal Protocol and Title VI of the Clean Air Act Amendments of 1990, or equivalent overall air quality benefits that take into account lifecycle impacts.

The RPL currently operates units containing hydrochlorofluorocarbon (HCFC) refrigerants. HCFCs are identified in the 1992 amendment to the Montreal Protocol as less damaging to the ozone layer than chlorofluorocarbons (CFC), but still containing ozone-destroying chlorine. A schedule of units and their associated refrigerants is shown in Table 6.2 below.

Table 6.2. RPL Units Containing HCFC Refrigerants

\begin{tabular}{lc}
\multicolumn{1}{c}{$\underline{\text { Unit }}$} & Refrigerant \\
Heat Pump A, Room 209 & R-22 \\
Heat Pump B, Room 209 & R-22 \\
206 Shop Heat Pump & R-22 \\
Lunch Room Heat Pump & R-22 \\
Front Office Chiller & R-22 \\
Process Chiller & R-22 \\
Room 202/203 Air Handlers & R-22 \\
HLRF Air Conditioner & R-22 \\
Power Operator Office AC & R-22
\end{tabular}




\begin{tabular}{lc} 
525 Walk-In Cooler & Refrigerant \\
\cline { 2 - 2 } Mezzanine Air Handler & R-22 \\
300 Ton Main Chiller A & R134A \\
300 Ton Main Chiller B & R134A
\end{tabular}

The Montreal Protocol, as amended, is carried out in the United States through Title VI of the Clean Air Act. Under the terms of the Montreal Protocol, there is a phaseout schedule for HCFCs, including R22. PNNL is committed to the elimination of ozone depleting compounds on its campus. Considering lifecycle impacts, replacement of older units using HCFCs is underway. PNNL Acquisition Guideline 24 requires the purchase of Class 2 ozone depleting substance alternatives within the following sectors: refrigeration and air-conditioning, foam blowing agents, cleaning solvents, fire suppression and explosion protection, aerosols, sterilants, tobacco expansion, adhesives, coatings, and inks. The Acquisition Guideline also requires alternatives to Class 1 ozone depleting substances, such as CFCs, Halons, carbon tetrachloride, methyl chloroform, methyl bromide, and hydrobromofluorocarbons.

As units require replacement or as a result of a changing mission need, existing equipment will be replaced with equipment that uses approved HCFC alternatives. Currently underway is a project to replace the RPL process chiller with a new model using HCFC substitute R410-A. A second project is also currently in construction to remove the air handlers serving rooms 202 and 203. These rooms will soon be cooled using facility chilled water. 


\subsection{References}

American Society of Heating, Refrigerating, and Air-Conditioning Engineers (ASHRAE). 2010. Standard 55-2004 - Thermal Environmental Conditions for Human Occupancy. American Society of Heating, Refrigerating, and Air-Conditioning Engineers, Atlanta, Georgia.

American Society of Heating, Refrigerating, and Air-Conditioning Engineers (ASHRAE). 2010. Standard 62.1-2010 - Ventilation for Acceptable Indoor Air Quality. American Society of Heating, Refrigerating, and Air-Conditioning Engineers, Atlanta, Georgia.

Energy Efficiency \& Renewable Energy (EERE). 2007. "Section 432: Federal Facility Management and Benchmarking Requirements,” Energy Independence and Security Act. EERE, U.S. Department of Energy, Washington, D.C.

Executive Order 13423. January 24, 2007. “Strengthening Federal Environmental, Energy, and Transportation Management.” The White House, Federal Register.

Executive Order 13514. October 5, 2009. “Federal Leadership in Environmental, Energy, and Economic Performance.” The White House, Federal Register.

Montreal Protocol. September 16, 1987. The Montreal Protocol on Substances that Deplete the Ozone Layer. Vienna Convention for the Protection of the Ozone Layer, 1987.

Pacific Northwest National Laboratory (PNNL). 2013. ASHRAE 62.1-2007 Analysis Report. Pacific Northwest National Laboratory, Richland, Washington.

Pacific Northwest National Laboratory (PNNL). 2013. Basic Staff Practices. HDI Work Control, Pacific Northwest National Laboratory, Richland, Washington.

Pacific Northwest National Laboratory (PNNL). 2013. F\&O Administrative Procedure: Managing Sustainability Program Requirements. ADM-142, Pacific Northwest National Laboratory, Richland, Washington.

Pacific Northwest National Laboratory (PNNL). 2013. F\&O Standard Operating Procedure: 325 Operator Rounds. SOP-325-RND-01, Pacific Northwest National Laboratory, Richland, Washington.

Pacific Northwest National Laboratory (PNNL). 2013. PNNL Acquisition Guideline 24: Sustainable Acquisitions. Pacific Northwest National Laboratory, Richland, Washington.

Pacific Northwest National Laboratory (PNNL). 2013. Site Sustainability Plan: An Authentic Commitment. PNNL-22109, Pacific Northwest National Laboratory, Richland, Washington.

Pacific Northwest National Laboratory (PNNL). 2012. F\&O Administrative Procedure: Engineering Design Standards. ADM-CM-057, Pacific Northwest National Laboratory, Richland, Washington. 
Pacific Northwest National Laboratory (PNNL). 2012. Metering Plan: Monitoring Energy and Potable Water Use in PNNL EMS4 Buildings. Pacific Northwest National Laboratory, Richland, Washington.

U.S. Environmental Protection Agency (EPA). 1990. “Title IV - Stratospheric Ozone Protection,” Clean Air Act Amendment. U.S. Environmental Protection Agency, Washington, D.C. 


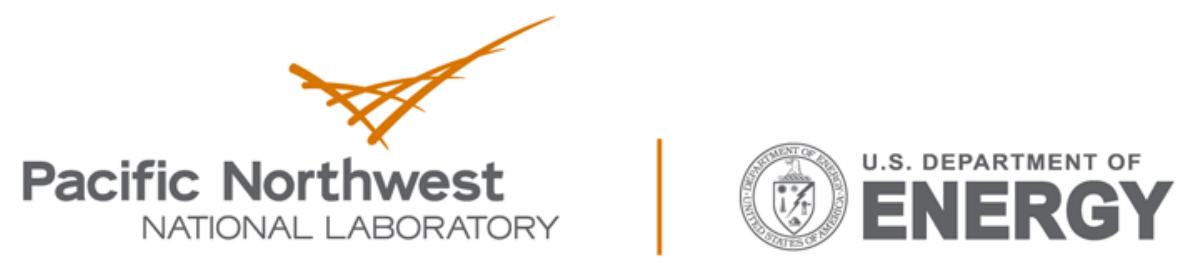

Proudly Operated by Battelle Since 1965

902 Battelle Boulevard

P.O. Box 999

Richland, WA 99352

1-888-375-PNNL (7665)

www.pnnl.gov 